\title{
Deep Drilling on
}

Midway Atoll

GEOLOGICAL SURVEY PROFESSIONAL PAPER 680-A

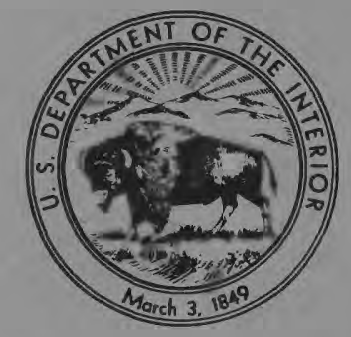


Deep Drilling on

Midway Atoll

By HARRY S. LADD, JOSHUA I. TRACEY, JR., and M. GRANT GROSS

GEOLOGY OF THE MIDWAY AREA, HAWAIIAN ISLANDS

GEOLOGICAL SURVEY PROFESSIONAL PAPER 680-A

Two cores recovered from the reef cap and

the basaltic foundation establish a

Tertiary section for the Hawaiian Islands

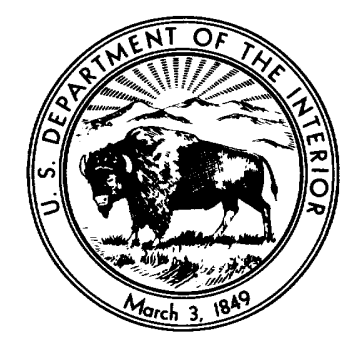

UNITED STATES GOVERNMENT PRINTING OFFICE, WASHINGTON : 1970 


\section{UNITED STATES DEPARTMENT OF THE INTERIOR}

WALTER J. HICKEL, Secretary

\section{GEOLOGIGAL SURVEY}

William T. Pecora, Director

For sale by the Superintendent of Documents, U.S. Government Printing Office Washington, D.C. 20402 - Price $\$ 1$ (paper cover) 
DEEP DRILLING ON MIDWAY ATOLL 


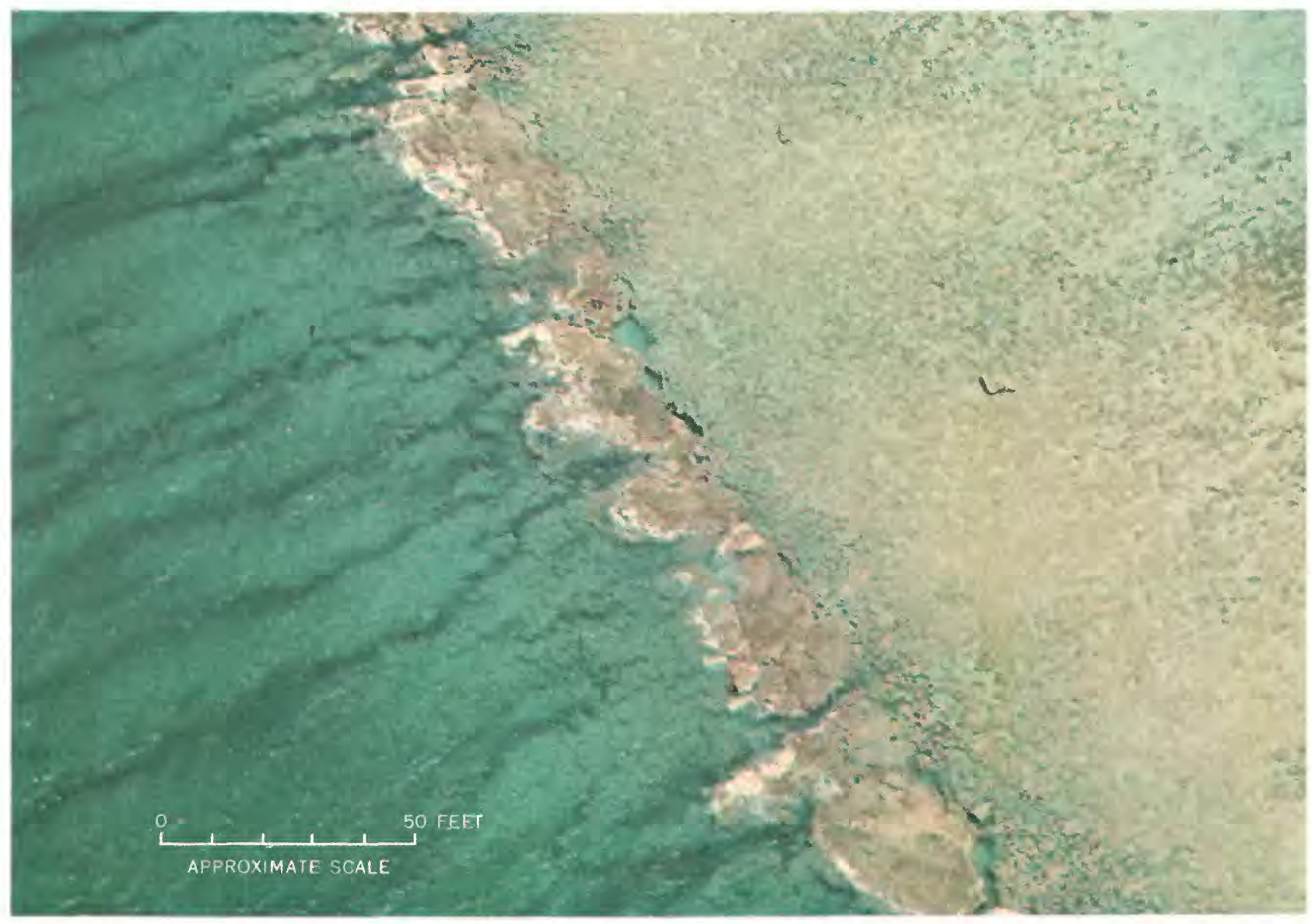

The windward reef, Kure. The irregular red-brown buttresses, composed of living algae, are bordered to seaward by irregular submarine grooves and ridges; the reef flat, built of corals and algae (right), extends toward the lagoon. 


\section{CONTENTS}

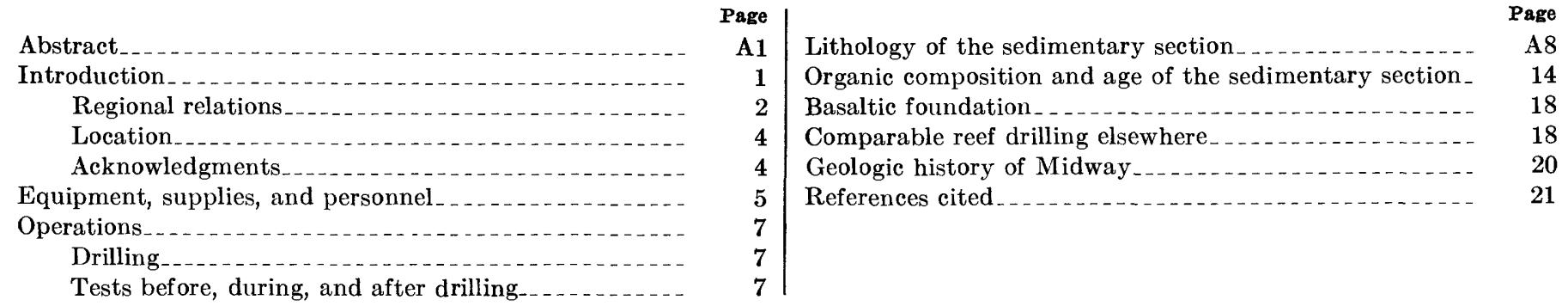

\section{ILLUSTRATIONS}

Frontispiece. The windward reef, Kure.

Page

Plate 1. Bathymetric chart of Midway area

Figure 1. Index map of the Hawaiian chain

2. Map of the Pacific basin, showing major tectonic features.

3. Photograph showing mass of living coral on floor of Midway lagoon

4. Map of Midway atoll, showing location of drill holes

5. Aerial photograph of Sand Island.

6. Photographs showing drilling preparations and operations

7. Logs of drill holes

8-17. Photographs showing cores from the Reef hole:

8. Reef limestone at 119 feet...

9. Fragmental limestone at 414 feet.

10. Dolomite at 474 feet.

11. Dolomitic limestone breccia at 588 feet

12. Extensively leached limestone at 646 feet.

13. Variegated limy dolomite at 914 feet...

14. Fragments of mollusk shells in clay at 987 feet

15. Light-gray tuffaceous limestone containing molds of corals and mollusks at 993 feet_........

16. Light-gray to medium-light-gray tuffaceous limestone containing molds and coral fragments at 1,030 feet

17. Dark clay containing bivalve shells at 1,046 feet

18. Photographs showing cores from the Sand Island hole

19. Map showing sites of deep holes drilled on five atolls in the open Pacific Ocean

20. Graphic summary of results of deep drilling on five atolls in the open Pacific Ocean

\section{TABLES}

TABLE 1. Summary of depths, casing depth, and core recovery for two diamond drill holes

2. Major lithologic units of the Sand Island and Reef drill holes-------

3. Description of cores and cuttings from the Sand Island and Reef drill holes

4. Data from deep drilling on five atolls in the open Pacific Ocean 



\title{
GEOLOGY OF THE MIDWAY AREA, HAWAIIAN ISLANDS
}

\section{DEEP DRILLING ON MIDWAY ATOLL}

\author{
By Harry S. Ladd, Joshua I. Tracey, Jr., and M. Grant Gross
}

\begin{abstract}
Two deep drill holes through reef limestones and underlying clays into basalts establish a geologic section for the Hawaiian Islands that extends back through the Miocene. Chemical analyses indicate that tholeiitic basalts were covered by flows of alkalic basalts, and aa and pahoehoe structures indicate that the volcanic mound was built above the sea. The exposed part of the volcanic mound was partly truncated by wave action in pre-Miocene time, after which subsidence began. As the mound sank, weathered clays were reworked in shallow water and eventually were covered by reef limestones. Overall submergence was interrupted three or more times by emergenceduring the middle Miocene, at the end of the Miocene, and at least once during the Pleistocene. During periods of emergence, the limestones were leached and recrystallized. The Miocene limestone is irregularly dolomitized. This alteration may have occurred at the time the lower part of the post-Miocene section was deposited and extensively dolomitized. The altered limestones were covered by 200 feet of younger reef limestones. The last-recorded event was the growth of a now emergent reef, eroded remnants of which are found on most of Midway's rim.

\section{INTRODUCTION}

Midway atoll and its neighbor Kure lie at the northwest end of the Hawaiian chain, which stretches for more than 1,600 miles across the central Pacific (fig. 1). The entire chain can be conveniently divided into three major subdivisions according to the type of island found in each (Palmer, 1927, p. 5). The southeast segment includes the large volcanic islands and their associated small islets. The middle segment includes several shoals, in addition to small islands, on which volcanic rock is exposed. The northwest segment stretches over a greater distance than the other two and includes a dozen or more shoals and reefs; some of these reefs, like Midway and Kure, have low-lying carbonate-sand islets, but no volcanic material is exposed.

This overall distribution of high-altitude volcanic rocks and sea-level reefs impressed early observers, and significant interpretations resulted. Charles Darwin (1842), in his volume on coral reefs, referred to the smaller islands and reefs that form the northwest segment (p. 158-159). Darwin had not visited the area and could not find satisfactory descriptions of the small islands and reefs of Kure, then called Ocean Island. This atoll was described by Couthouy (1842), whose paper was also published in 1842, but Darwin had seen Couthouy's writings in a pamphlet sent to him earlier by Charles Lyell. Couthouy's description of the atoll led Darwin to color Kure blue on his reef map, thus indicating subsidence; on the same map Darwin colored the larger Hawaiian (Sandwich) Islands red to indicate emergence.

Dana (1843, p. 134-135) referred to the small rocky and coral islets beyond the main islands of Hawaii. He noted that they evidently belonged to one series, adding, "I will not say that there is a connection between the trend of these groups and the area of subsidence; yet it looks much like it." In the larger islands he noted that igneous eruptions became more recent toward the southeast. Dana expressed the opinion that subsidence was no longer in progress and suggested that it may have taken place in the latter part of the Tertiary and succeeding ages. Later, in his main report as geologist for the United States Exploring Expedition under Charles Wilkes, Dana (1849, p. 280) stated that the Hawaiian eruptions might date as far back as "the early carboniferous or Silurian epoch," but he never stated what he considered evidence for this conclusion, as far as we can determine. In this same report Dana noted (p. 396-397) that the western islands were coral islands, indicating participation in subsidence, and concluded that the change of level was greatest at the west extremity of the Hawaiian chain. Dana also referred (1849, p. 282-283) to a manuscript by Couthouy in which that author recognized that the progress of volcano extinction in the Hawaiian chain was from the west to the southwest.

Geologists working later in the Hawaiian Islands have found no reason to question the general theory of progressive volcanism and subsidence from northwest to southeast. They have recognized, as did Dana (1849, p. 281), that the chain is not a single line of vents but 


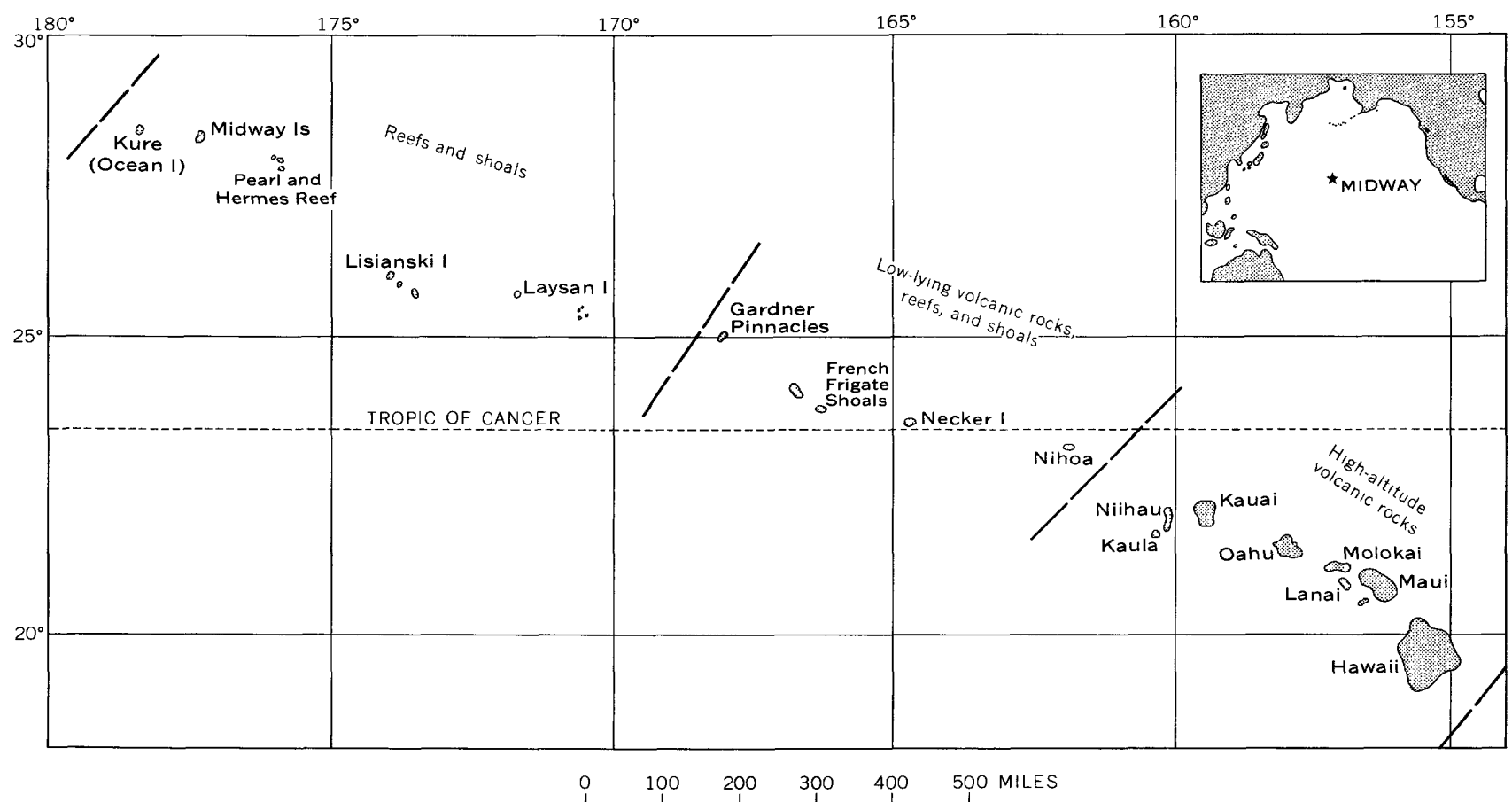

FiguRe 1.-The Hawaiian chain, showing the three major physiographic subdivisions (bounded by dashed lines). Modified from Palmer (1927).

that there are transverse fissures along which eruptions have occurred. The order of extinction has probably not been a simple northwest-southeast series, nor has progress necessarily been uniform. Nevertheless, a general trend is discernible the atolls on the west reflect greater subsidence than the reef-fringed high-altitude volcanic islands on the east.

The preparation, in recent years, of detailed bathymetric charts in the Hawaiian area has revealed the presence of many seamounts near the main trend of the Hawaiian chain. These seamounts presumably represent separate volcanic vents. None of them reaches the surface of the sea today, but the flat tops of many (several are shown on pl. 1) suggest that at one time they formed islands that were truncated by wave action. None have been dredged or otherwise sampled. The relation of Midway to these structures is discussed in the section on geologic history.

If the sequence of events outlined above is correct, geologic sections beneath the western reef islands might contain a record of much of the history of the Hawaiian Islands. To test this postulated history, Harry S. Ladd proposed in 1960 that a deep hole be drilled on Midway; this atoll was selected over its neighbor Kure for logistical reasons.

A preliminary report on the drilling was published in 1967 (Ladd and others, 1967). Much of the material in the preliminary report is included in the present paper.

\section{REGIONAT RELATIONS}

The Hawaiian chain compares favorably in size with older and more complex mountain chains in other parts of the world. Since the mid-19th century, when Couthouy, Darwin, and Dana speculated about submergence and the migration of volcanic action in the Hawaiian chain, much detailed geologic mapping has been done in the area and many oceanographic and geophysical surveys have been carried out. Literature on the area is voluminous and will not be reviewed in detail here. The latest overall summary is given in "Geology of the State of Hawaii" (Stearns, 1966). This work is based largely on land surveys by Stearns and several collaborators, particularly Gordon A. Macdonald, and was published originally in a series of bulletins by the Hawaii Division of Hydrography. Excellent discussions of the submarine geology of the area have been presented by Dietz and Menard (1953), Emery (1955), Hamilton (1957), and Moberly and McCoy (1966). Before doing seismic work at Midway in connection with the drilling project, George Shor investigated the crustal structure of the Hawaiian Ridge near Gardner Pinnacles (Shor, 1960). A recent volume on the marine geology of the Pacific (Menard, 1964) includes a discussion of major tectonic features and outlines the probable listory of the entire Pacific. Many papers dealing with geological, geochemical, and geophysical studies of the Hawaiian Ridge were brought together in a special issue of "Pacific Sci- 
ence" by George P. Woollard (Woollard and others, $1965)$.

Figure 2 shows some of the major tectonic features of the Pacific Ocean basin. The Andesite line around the margin of the Pacific is usually considered as the structural boundary between the ocean basin and the adjacent continents. Fsland arcs and their associated trenches lie outside this line. These features are best developed in the southwest and west Pacific, but the
Aleutian Islands and their associated trench in the north Pacific also form a true arc. On the east side of the Pacific lie the remarkable fracture zones that extend westward from the Americas to near the middle of the Pacific. The approximate locations of two important rises are also shown in figure 2. The East Pacific Rise parallels the west coast of the Americas and is still tectonically active. The other rise shown is the former Darwin Rise, an area now apparently inactive tectoni-

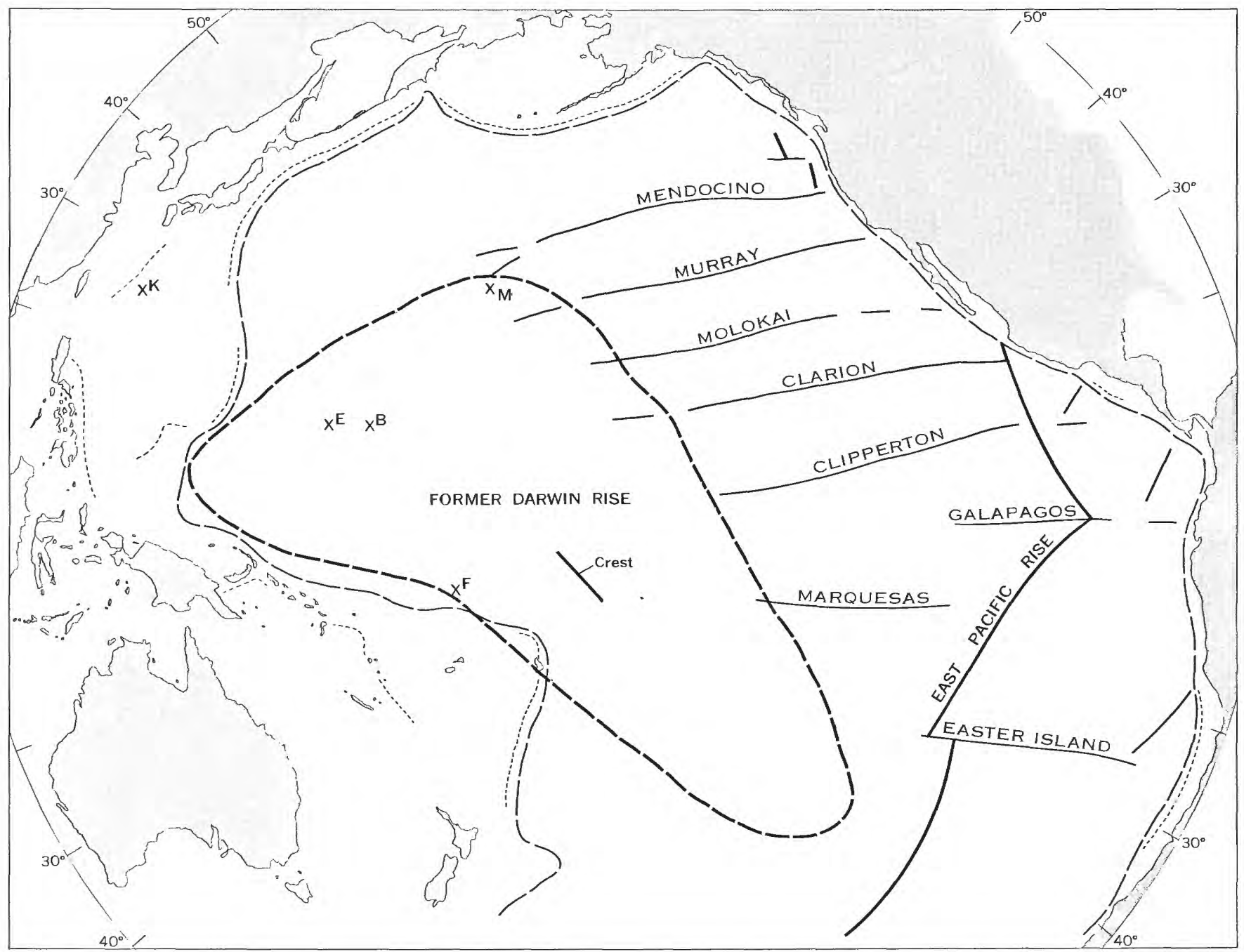

EXPLANATION

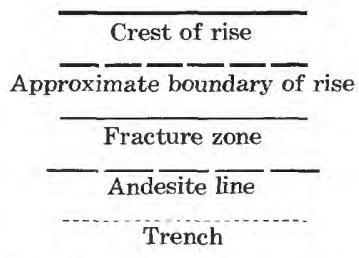

$$
\begin{aligned}
& \quad \mathrm{x} \\
& \text { Deep-drilling sites } \\
& \text { B, Bikini } \\
& \text { E, Eniwetok } \\
& \text { F, Funafuti } \\
& \text { K, Kita-daitō-jima } \\
& \text { M, Midway }
\end{aligned}
$$

Figure 2.-Some major tectonic features in the Pacific Ocean basin and the location of the former Darwin Rise in relation to Midway and other deep-drilling sites. Modified from Menard $(1965,1967)$. 
cally and deeply submerged. Its boundary as drawn by Menard, encloses most atolls of the open Pacific, including Midway and Kure (Hess, 1960, 1965; Menard, 1964, 1965).

The southeastern segment of the Hawaiian Ridge is superimposed on a low bulge of the ocean floor, the Hawaiian Swell. The Hawaiian Trough (Deep) along the northeast edge of the ridge extends around the southeast end of the ridge. Beyond the trough is a broad arch. Some evidence suggests that these major submarine features extend northwestward to Midway and Kure (Dietz and Menard, 1953, p. 100, 105), but this extension has not yet been clearly demonstrated.

As shown in figure 2, two great fracture zones of the eastern Pacific - the Molokai and the Murray fracture zones - extend into the Hawaiian Islands area. They do not offset the Hawaiian Ridge, and the ridge apparently was superimposed on the fracture zones (Menard, 1967, p. 74). However, the southern Hawaiian Islands appear to be affected by recent faulting along the Molokai fracture zone, because vulcanism is localized along the eastwest magnetic trends of the fracture zone (Malahoff and others, 1966, p. 521).

Several explanations for the origin of the Hawaiian Ridge and associated tectonic features have been suggested, and investigations are continuing. The explanations offered have involved faulting, crustal buckling, convection currents, and sea-floor spreading. In relation to the Hawaiian Islands, we favor the view expressed by Hamilton (1957, p. 1011) that the structures are. probably due to a response of the earth's crust to the great load of the Hawaiian Ridge, whatever may have been the cause of the outpouring of lava.

\section{LOCATION}

Midway and Kure lie close to lat $28^{\circ} \mathrm{N}$. (fig. 1), outside the tropics, and are, in fact, the northernmost atolls existing today.

Midway is a subcircular reef about 6 miles in diameter on a platform rising from a depth of more than 2,000 fathoms. The reef is discontinuous on the northwest, and on the south a narrow opening has been widened and deepened for purposes of navigation. Its lagoon is shallow; a maximum depth of 75 feet is found near its center, but average depths are much less. The northeastern part is a shallow lagoonal terrace with depths generally less than 10 feet; the lagoon supports a rich growth of coral (fig. 3). Two low islands are found on the south side of the atoll, Sand Island to the west and Eastern Island to the east (fig. 4). Sand Island (fig. 5), the larger, has a maximum diameter of $21 / 2$ miles and its highest sand hill originally rose to a height of 43 feet (Bryan, 1906, p. 39).

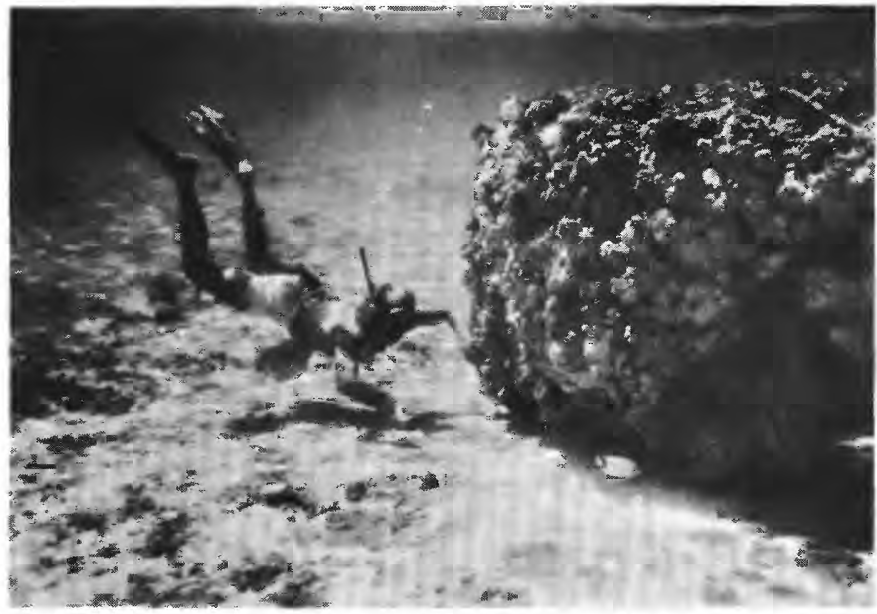

F'IGURE 3.-Mass of living coral on floor of Midway Yagoon.

Kure lies about 60 miles west-northwest of Midway and also rises from a depth of more than 2,000 fathoms. It is bordered by a flourishing reef composed of algae and corals (frontispiece). The lagoon has a maximum depth of about 50 feet. A single islet, Green Island, lies on the southeast. There are small breaks in the reef, west and east of Green Island, but no navigable channel.

\section{ACKNOWLEDGMENTS}

The drilling described in this report was carried out under the auspices of the Hawaii Institute of Geophysics, University of Hawaii, with financial support (grant No. GP4728) from the National Science Foun-

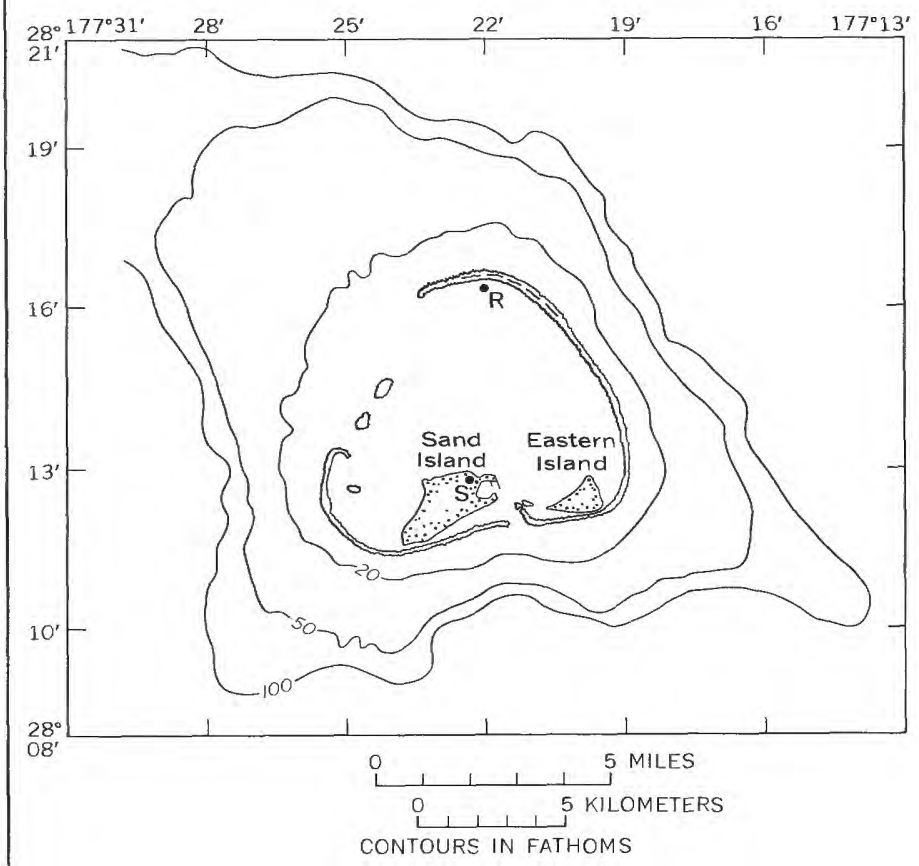

Figure 4.-Midway atoll, showing location of drill holes. S, Sand Island hole; $\mathbf{R}$, Reef hole. 


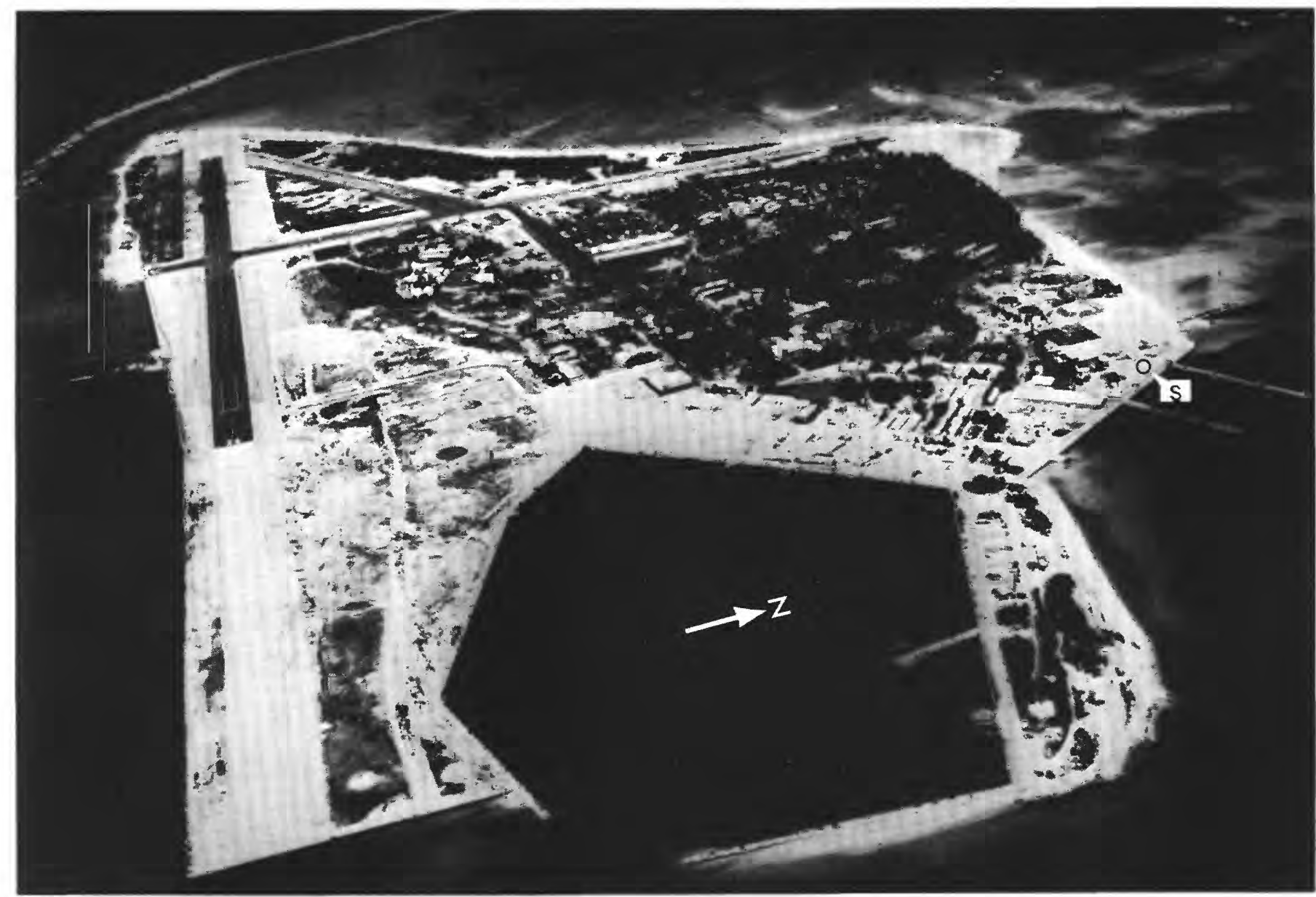

Figure 5.-View of Sand Island, Midway. S, Sand Island drill hole. Maximum diameter of island 2.5 miles. Copyright 1964, National Geographic Society.

dation. Members of the scientific personnel were furnished by the U.S. Geological Survey, University of Washington, and University of Hawaii. The U.S. Office of Naval Research arranged for the use of a Navy barge to serve as a drilling platform for the Reef hole. In planning the work, Ladd was assisted by Dr. George P. Woollard and Dr. Gordon A. Macdonald, University of Hawaii, coinvestigators in the project. In connection with planning, thanks are also due to Dr. William E. Benson of the National Science Foundation, the late V. C. Mickle of the George E. Failing Co., Rear Adm. Charles W. Thomas, USCG (Ret.), Capt. Jesse Burks, USN, and George Rollinson of the University of Hawaii. During our stay at Midway, Capt. F. D. Milner, USN, Commanding Officer, and his associates cooperated fully. Special thanks for assistance are due Lt. John Economides, USN, and Mr. L. P. Rossiter of the Public Works Department, Midway. In connection with the identifications of fossil mollusks, Ladd has benefitted from discussions with Dr. Alan Solem of the Field Museum of National History, Chi- cago, and Prof. Alison Kay of the University of Hawaii. We are indebted to Dr. Robert N. Ginsburg of Johns Hopkins University and Dr. S. O. Schlanger of the University of California, Riverside, who read the manuscript critically and offered valuable suggestions.

\section{EQUIPMENT, SUPPLIES, AND PERSONNEL}

The drill rig was a truck-mounted Failing Model 2500 with reinforced tower. Cuttings and cores to a depth of 70 feet in each hole were taken with conventional rock bit and diamond core barrel. At depths greater than 70 feet a rubber-sleeve core barrel (Austin, 1959), yielding a 3 -inch core, was used almost exclusively. In the deeper hole, the Reef hole, three 1-inch-diameter oriented cores were taken. The size and amount of casing used and the amounts of core recovered are shown in table 1 . Sea water mixed with saltwater mud was used as drilling fluid.

The first hole was drilled without difficulty on Sand Island (fig. 6A). Geophysical surveys (Shor, 1963, 1964) had indicated a thickening of the section to the 

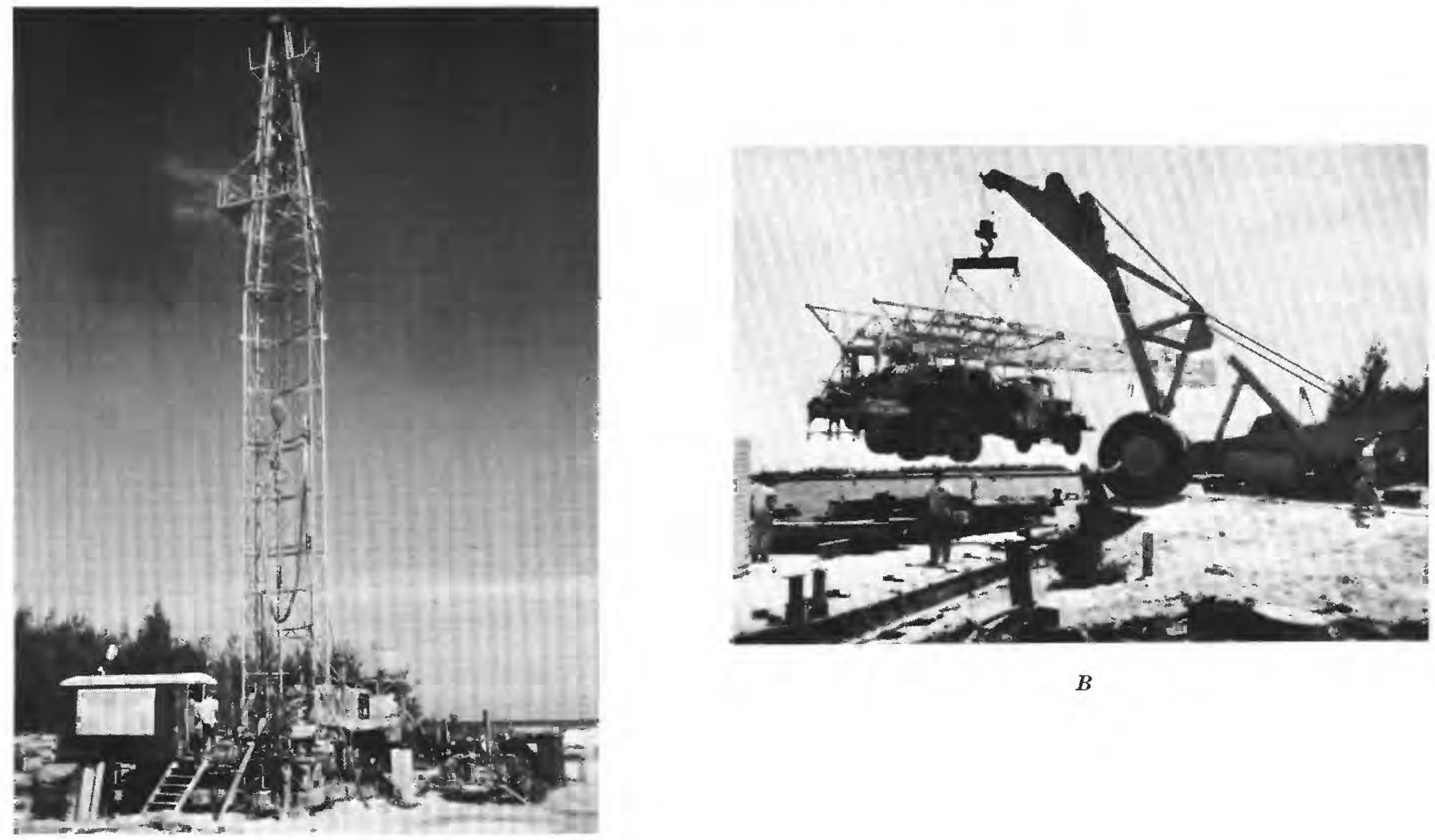

$\boldsymbol{B}$

$A$

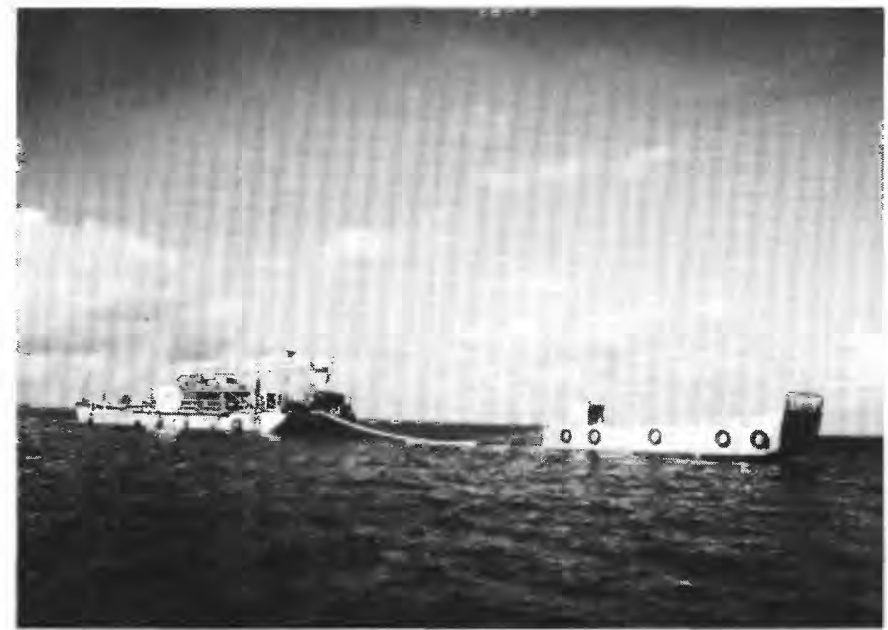

$C$

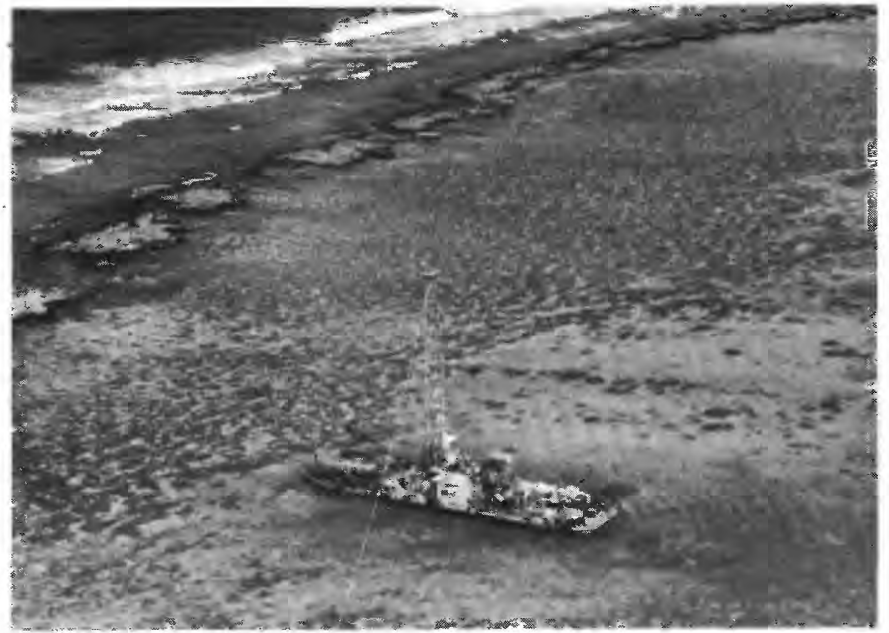

$D$

Frgure 6.-Drilling preparations and operations. $A$, Drilling at Sand Island site. $B$, Loading of truck-mounted rig on barge for transport to Reef hole site. Photograph by William Craddick, Layne International, Inc. $C$, Towing of barge and drill across the lagoon to Reef hole site. $D$, Drill rig on barge resting on lagoon floor in 8 feet of water near the north edge of lagoon. The light areas around the barge are sand; the dark areas are living corals and algae. The dark-bordered irregular areas (upper left) are eroded remnants of an older reef now several feet above sea level. Beyond the old reef lies a narrow reef platform on which the waves of the open sea are breaking. Photograph by Comdr. N. R. Wooden, USN. 
TABLE 1.-Summary of depths, casing depth, and core recovery for two diamond drill holes

\begin{tabular}{|c|c|c|c|c|c|}
\hline Hole & $\begin{array}{c}\text { Total } \\
\text { depth } \\
\text { (ft) }\end{array}$ & Casing depth (ft) & $\begin{array}{l}\text { Footage } \\
\text { cored with } \\
\text { rubber- } \\
\text { sleeve c're } \\
\text { barrel (ft) }\end{array}$ & $\begin{array}{c}\text { Core } \\
\text { recovery } \\
\text { (ft) }\end{array}$ & $\begin{array}{c}\text { Core } \\
\text { recovery } \\
\text { (percent) }\end{array}$ \\
\hline Sand Island ....- & 568 & $\begin{array}{l}122\left(12^{3} / 4 \text {-in. OD }\right. \\
\text { casing). }\end{array}$ & 481.5 & 346.8 & 72 \\
\hline Reef-. & 1,654 & $\begin{array}{l}190 \text { (16-in. OD cas- } \\
\text { ing);800 (12-in. OD } \\
\text { casing). }\end{array}$ & $1,358.5$ & $1,254.8$ & 92 \\
\hline
\end{tabular}

north under the lagoon; consequently, the site for the second hole was a flat sandy area just inside the reef on the north side of the lagoon, where the depth of water at high tide is 8 feet. This site was cleared of minor coral growth, and a course through the coral-studded lagoonal terrace was mapped by divers and marked with buoys.

The drill and all equipment, weighing 120 tons, were loaded aboard a steel barge measuring 120 by 30 feet (fig. $6 B$ ). The barge, furnished by the U.S. Navy, was then towed to the drill site by a Navy LCM (fig. $6 C$ ). After being jockeyed into position at the drill site, the barge was pumped full of sea water so that it settled to rest firmly on the sand bottom (fig. $6 D$ ). The drill tower, when raised, was guyed to nearby massive coral heads and the steel piling of an abandoned loran station.

All drilling was done under the supervision of William Craddick of Layne International, Inc. Two crews totaling seven men operated the drill continuously in 12-hour shifts. A geologist or geological assistant was on duty at all times. In this work we were assisted by Theodore K. Chamberlain, W. Storrs Cole, William Ebersole, and Ted Murphy. Charles E. Ward of Christensen Diamond Products Co. directed the taking of the oriented cores of the basalt section.

\section{OPERATIONS}

Before attempting the expensive process of drilling, seismic and magnetic surveys were carried out to determine the approximate thickness of the postulated cap of reef rock. Two seismic surveys were made by George Shor and associates of the Scripps Institution of Oceanography. The first, along the south side of Sand Island, was made in May 1963 (Shor, 1963, 1964); the second survey, in the lagoon, was made in December of 1964 specifically to determine the thickness of coral beneath the northern part of the lagoon (Shor and others, 1964) where a magnetic low had been reported by the U.S. Naval Oceanographic Office (U.S. Naval Oceanographic Office, 1963, 1966). The geophysical surveys indicated that a significant section of sediments was present beneath the islands on the south and that the section progressively thickened northward under the lagoon.

\section{DRILLING}

Two holes were drilled during the summer of 1965 (fig. 4). The first hole, on Sand Island, entered basalt at a depth of 516 feet, and drilling was continued to 568 feet. The rotary table, from which depths were measured, was 16.5 feet above datum (mean lower low water). The second, the Reef hole, was drilled from a barge resting on the north edge of the lagoon floor; the rotary table was 10.5 feet above datum and 16 feet above the lagoon floor. Reef hole entered basalt at a depth of 1,261 feet, and drilling was continued to 1,654 feet. In each hole, about 400 feet of post-Miocene limestones was penetrated, below which was a thin zone of upper Miocene (Tertiary $g$ ) sediments. In the Reef hole, upper Miocene sediments were underlain by approximately 500 feet of lower Miocene limestones (Tertiary $e$ ), and these were underlain by about 170 feet of reworked volcanic clays, some lignitic, also of early Miocene age.

No serious difficulties were encountered in drilling the Sand Island hole. Circulation was lost on occasion in the unconsolidated layers at shallow depths but was regained after setting casing to a depth of 122 feet. Circulation was lost again at lower levels, and parts of the hole were cored without circulation. Overall core recovery was 72 percent.

Loss of circulation was also a minor problem in drilling the deeper Reef hole, and two strings of casing were set to control it (table 1). A survey of the Reef hole showed a deviation from the vertical of 49 feet at a depth of 1,480 feet; at total depth 1,654 feet, the deviation was estimated at 62 feet. The chief difficulties with the Reef hole involved servicing the rig and changing crews for continuous operation at a site more than 4 miles by water from our base on Sand Island.

Cores and cuttings have been placed on permanent deposit in Honolulu with the Hawaii Institute of Geophysics, University of Hawaii.

\section{TESTS BEFORE, DURING, AND AFTER DRILLING}

Before and during drilling of the Sand Island hole, George V. Keller of the Colorado School of Mines made surface resistivity soundings on Sand and Eastern Islands, Midway, on Green Island, Kure, and at four depth intervals in the Sand Island hole itself. These soundings were attempts to evaluate the possible use of resistivity surveys in studying coral atolls.

Thomas H. Moses, Jr., U.S. Geological Survey, took temperature readings in both drill holes to determine the thermal gradient. This was successfully done in the Sand Island hole where a water pipe had been installed from the surface to the bottom of the hole to prevent 
closure. In the Reef hole, readings were not obtained all the way to bottom, because the hole had bridged below the casing that was set to a depth of 800 feet. The lower part of the Reef hole had been left uncased to facilitate a seismic in-hole survey.

After completion of drilling, George Shor, assisted by Alan C. Jones, who had participated in the earlier seismic surveys of Midway, ran an additional refraction profile in the lagoon near the drill site and made in-hole measurements in both holes. In the Reef hole this survey was not completely successful because, as previously mentioned, the hole had bridged below the casing, and hydrophones could not be lowered all the way to bottom.

Full reports on all the above mentioned tests are being prepared for publication.

\section{LITHOLOGY OF THE SEDIMENTARY SECTION}

Limestones and partly lithified carbonate sediments dominate the Midway cores. A summary description of the major lithologic units in each hole is given in table 2 , and a more detailed lithologic description is given in table 3. In both holes the parts of the section immediately overlying the basalts contain an abundance of volcanic detrital material; grain sizes range from basalt pebbles to clay (fig. 7). The basalt cores also record a history of weathering and erosion before deposition of the sedimentary section; details of the basalt section are discussed by Macdonald (1969).

The Reef hole section down to a depth of about 489 feet consists primarily of reef or near-reef carbonate sediments (or their lithified equivalents) that contain abundant corals and coralline algae as fragments or in growth position (fig. 8). Between 250 and 385 feet the original sediments were dominately finer grained carbonate sands and muds; they are now partly lithified. The conspicuous change at about 210 feet (fig. 7 ) marks the transition from little-altered carbonate sediment to hard limestone; this is probably a solution unconformity (Schlanger, 1963, p. 994).

In the Reef hole, limestone containing Foraminifera and algal fragments is common, especially below a depth of 386 feet (fig. 9). Dolomite has uniformIy re-. placed the algal-foraminiferal limestone between depths of 426 and 489 feet (fig. 10). The original structures of dolomitized algae and foraminifers are beautifully preserved, and the dolomitization evidently took place before extensive leaching and recrystallization had occurred.

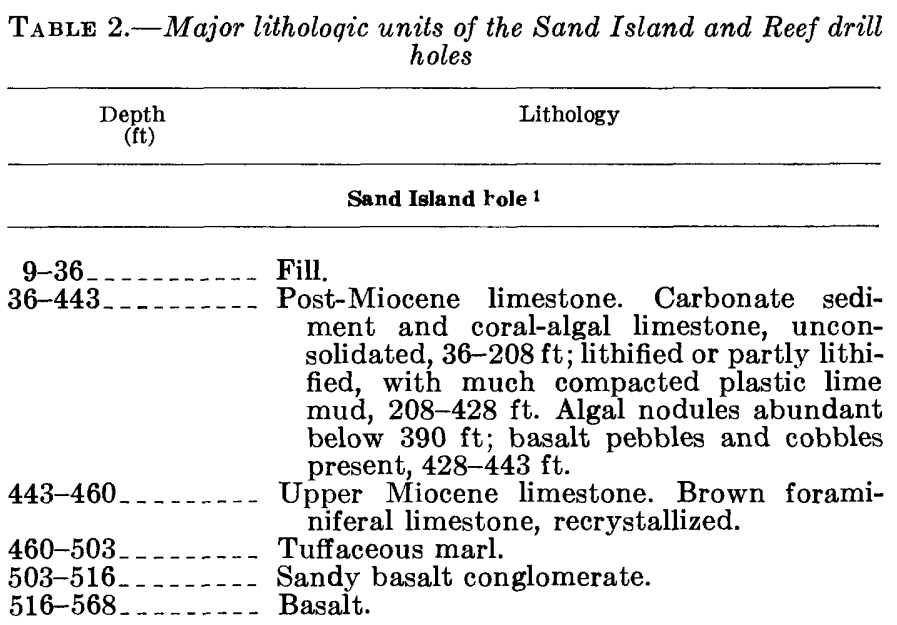

Reef hole ${ }^{2}$

16-489 _. . . . . . Post-Miocene limestone and dolomite. Carbonate sediment and coral-algal limestone, unconsolidated, 16-210 ft; lithified or partly lithified below 210 ft. Algalforaminiferal limestone below about 386 $\mathrm{ft}$; dolomite, 426-489 $\mathrm{ft}$.

489-563 . . . . . . . Upper Miocene limestone, gray molluscan and tan foraminiferal, recrystallized, vuggy; white porcelaneous dolomite partly fills vugs.

563-934 _... Lower Miocene limestone and dolomitic limestone. Detrital limestone and carbonate sand extensively leached, recrystallized to a rubble-and-sand mixture that in places appears almost like a cave breccia. Recrystallization has been to brown sparry calcite. Dolomite occurs as aphanitic void fillings and as clear or varicolored rhombs in vugs and interstices.

934-1,121........ Lower Miocene marl. Carbonaceous and calcareous shale, lignitic clay, tuffaceous limestone, and volcanic clay.

1,121-1,261 _... . Variegated volcanic clay and conglomerate. $1,261-1,654 \ldots \ldots$ Basalt.

1 Elev $16.5 \mathrm{ft}$ above mean lower low water.
2 Elev $10.5 \mathrm{ft}$ above mean lower low water.

FIGURE 7.-Logs of drill holes showing lithology, core recovery, and carbonate mineral composition. X-ray diffraction analysis was used to identify and estimate the abundance of carbonate minerals using 6-10 analyses of finely ground samples. The calcite contained less than $3 \mathrm{~mol}$ percent $\mathrm{MgCO}_{3}$ : Magnesium-calcite contained 10-17 mol percent $\mathrm{MgCO}_{3}$, averaging $13 \mathrm{~mol}$ percent, as estimated using the data of Goldsmith, Graf, and Joensuu (1955). The dolomites were shown to be calcium rich (about $45 \mathrm{~mol}$ percent $\mathrm{MgCO}_{3}$ ) using the data of Goldsmith and Graf (1958). No detailed data on dolomite structure or composition are available. 
DEEP DRILLING ON MIDWAY ATOLL

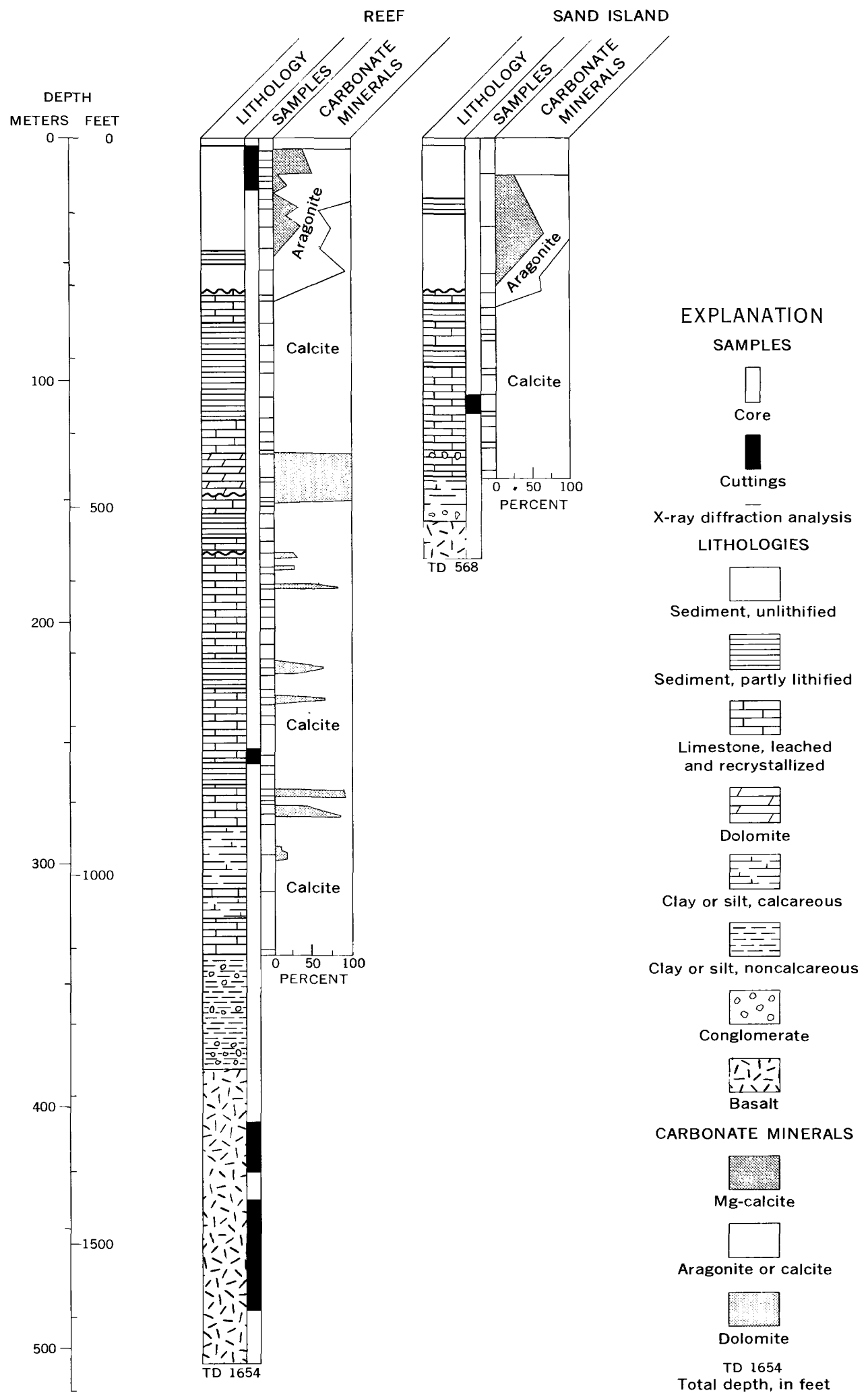


TABLE 3.-Description of cores and cuttings from the Sand Island and Reef drill holes

\begin{tabular}{lll}
\hline Depth (ft) & Lithology & Paleontology \\
\hline & Reef hole &
\end{tabular}

16-210 _. - _. _ - Carbonate sediment, unlithified, and coral-algal limestone (119 ft, fig. 8); massive coral at 90,134,149, and $160 \mathrm{ft}$; algae binding coral and other fragments, $130-140 \mathrm{ft}$; compacted fine white sand $(190 \mathrm{ft})$ and soft lime mud $(200 \mathrm{ft})$. Possible soil zone (brown mud and stained coral fragments), $77 \mathrm{ft}$. Minor lithification at $150 \mathrm{ft}$. Possible solution unconformities at 92 and $150 \mathrm{ft}$. Probable solution unconformity at $210 \mathrm{ft}$.

210-296 . . . . . . Fragmental limestone, consisting of algal, foraminiferal, and some coral fragments; partly leached and recrystallized, grading with increasing depth into partly lithified calcareous sand $(256-296$ $\mathrm{ft}$ ). Some casts and molds in the limestone; some small cavities lined with calcite crystals.

296-386 _. _. _ _ Partly lithified calcareous mud and sand. Detrital limestone below $296 \mathrm{ft}$. shows abundant solution features, and becomes more chalky and aphanitic, 314-370 ft. Soft lime mud and partly lithified foraminiferal sand, $370-386 \mathrm{ft}$.

386-426 . . . . . . Limestone, algal-foraminiferal. Friable at top; becomes harder with increasing depth, especially $400-426 \mathrm{ft}$. Abundant nodules and fragments of algae (fig. 9), foraminifers, corals, and mollusks. Extensive lithification below $400 \mathrm{ft}$.

426-489 _. _ _ _ _ Dolomite, algal-foraminiferal. Rock contains abundant nodules of algae and leached and recrystallized mollusks, as in unit above, but is uniformly dolomitized without loss of original structure (fig. 10). Fairly distinct contacts between dolomite and limestones at 426 and $489 \mathrm{ft}$. Loose algal nodules abundant, 467-474 ft. Unconformity at $489 \mathrm{ft}$.

489-563 . . . . . . Limestone, dolomitic, gray, abundant mollusk fragments, leached and recrystallized. Brown or clear sparry calcite fills molds. White porcelaneous dolomite occurs as patches, 489-505 ft. Partly lithified, tan foraminiferal sand contains hard angular nodules.

563 . . . . . Carbonaceous clay, plastic, dark-gray, 1-2-in. thick (possible unconformity).

563-633 . . . . . L Limestone, rubbly, nodular, dolomitic, extensively leached and recrystallized. Brown sparry calcite locally constitutes more than 50 percent of sample volume; dolomitic limestone breccia at $588 \mathrm{ft}$ (fig. 11). Dolomite occurs in aphanitic white void fillings, and below $600 \mathrm{ft}$ as disseminated minute rhombs (less than $0.5 \mathrm{~mm}$ across).

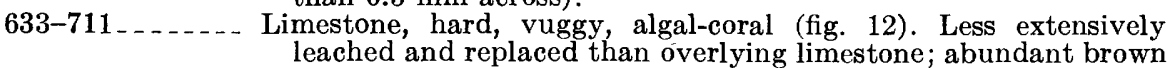
sparry calcite; coral-algal fragments especially abundant, 650$711 \mathrm{ft}$.

711-751 _... . . . Sand, dolomitic, partly lithified. Abundant coral-algal fragments. Disseminated minute dolomite rhombs (less than $0.5 \mathrm{~mm}$ across), $720-745 \mathrm{ft}$. 751-845 _. . . Limestone, cavernous, with abundant coral fragments. Friable to
loose sand and rubble, 760-769 ft. Dolomite crystals line cavities, $826-830 \mathrm{ft}$. No recovery, $811-826 \mathrm{ft}$.

845-885 ...... Sand, calcareous, partly lithified, changing to plastic lime mud with increasing depth.

885-934 _. . . . . . Dolomitic limestone containing orange dolomite rhombs. Abundant fragments of algae, coral, Foraminifera, mollusks. Reddishbrown clay layer containing limestone pebbles, $914 \mathrm{ft}$ (fig. 13). Partly lithified argillaceous dolomite sand, $925-930 \mathrm{ft}$.

934-995

Shale and marly limestone, gray to black carbonaceous calcareous shale and dark- to light-gray tuffaceous limestone, leached and recrystallized. Reef limestone section $(955-973 \mathrm{ft})$ contains abundant coral fragments, algae, and mollusk molds. Mottled gray calcareous and dark lignitic clay with abundant mollusk shells (fig. 14). Extensive lithification, slight dolomitization.

$995-1,121$

Volcanic clay, light- to dark-gray or olive-green, calcareous, containing layers of limestone at 1,043, 1,046, 1,049, and 1,116 ft. Gray tuffaceous limestone, partly leached (fig. 16).
Abundant small shallow-water marine gastropods, including Alcyna, Gibbula, Turbo, Synaptocochlea, Leptothyra, Tricolia, rissoids, vermetids, Bittium, Triphora, and Williamia; pelecypods include arcids and Chama. Endodontid land snails at 116-130 $\mathrm{ft}$.

Molds of large Cardium, 379-381 ft.

Abundant molds of large Pectens, 461-489 ft.

Valvulammina marshallana, Asterigerina tentorria, and Cribrogoesella parvula, 495$500 \mathrm{ft}$.

Miogypsinoides dehaartii, 590-600 ft.

Vicarya, $650 \mathrm{ft}$.

All coral molds, $801 \mathrm{ft}$.

A ustrotrillina striata, $901 \mathrm{ft}$. Miogypsinoides dehaartii, 901-906 ft; 926-927 ft.

Fragments of Pecten and molds of gastropods, 946-951 ft. Miogypsinoides dehaartii, 946$956 \mathrm{ft}$. Spiroclypeus margaritatus, 960-966 ft. Austrotrillina striata, Spondylus, and cerithids, $971 \mathrm{ft}$. Abundant brackish-water oysters, 978-979 $\mathrm{ft}$. Molds of corals and mollusks (arcids, venerids, and cerithids), 993-994 ft (fig. 15).

Spiroclypeus margaritatus, 1,029-1,121 ft. Amphistegina abundant, $1,045 \mathrm{ft} .1,043-$ $1,046 \mathrm{ft}$. (fig. 17). Astrotrillina, $1,117 \mathrm{ft}$. Molds of cerithids and venerids, 1,054$1,099 \mathrm{ft}$. 
TABLE 3.-Description of cores and cuttings from the Sand Island and Reef drill holes-Continued

\begin{tabular}{|c|c|}
\hline Depth (ft) & Lithology \\
\hline & Reef hole \\
\hline $1,121-1,261$ & $\begin{array}{l}\text { Volcanic clay, variegated; weathered calcareous nodules and } \\
\text { volcanic pebbles locally abundant. Some coral and algal frag- } \\
\text { ments. Basalt conglomerate layers, } 1,145-1,147,1,187-1,191 \\
1,214-1,216 \text {, and } 1,225-1,261 \text { ft. Lignitic clay, } 1,242-1,243 \text { and } \\
1,255, \mathrm{ft} \text {. }\end{array}$ \\
\hline
\end{tabular}

Paleontology

1,261-1,654_. _ _ Basalt, dark-gray, vesicular. Local alteration to claylike material, yellowish brown to dark grayish brown noncalcareous. Calcite in veins.

\section{Sand Island hole}

$9-36$

Fill, coral-algal sand and gravel

Unlithified carbonate sediment consisting of coral-algal fragments and soft calcareous mud (98 ft). Coral fragments abundant; massive coral at 78-83 and 195-206 ft. Coarse foraminiferal sand $(125-150 \mathrm{ft})$, partly lithified, contains abundant coral and algal fragments. Possible solution unconformities at 98 and 150 $\mathrm{ft}$. Probable solution unconformity at $208 \mathrm{ft}$. (fig. 18, left).

$208-245$

Limestone, partly leached and recrystallized; contains solution cavities $(208-215 \mathrm{ft})$. Compacted sand $(200-230 \mathrm{ft})$ and plastic lime mud (240-245 ft). Partial lithification 208-337 ft.

245-281....... Limestone, leached and recrystallized; contains abundant casts and molds. Calcite crystals line molds.

281-320_..... Compact lime mud, white with patchy consolidation forming aphanitic limestone that contains shell molds and small amounts of crystalline calcite.

320-337 _. . . . . Fragmental chalky limestone, aphanitic matrix; abundant coral and algal fragments, mollusk molds.

$337-427$ Limestone, leached and recrystallized, and partly lithified calcareous sand. Basalt pebble, approximately 1 in. in diameter at 405 ft (fig. 18). Extensive lithification, $337-370 \mathrm{ft}$; algal nodules abundant, $390 \mathrm{ft}$.

$427-443$ Buff, friable limestone, containing basalt pebbles and cobbles. Fine sand (442-443 ft) containing limestone pebbles and algal nodules. Possible unconformities at 427 and $443 \mathrm{ft}$.

$443-460$

Brown foraminiferal limestone, recrystallized. Partly lithified foraminiferal sand near base. Possible solution unconformity at $460 \mathrm{ft}$.

$460-503$

Tuffaceous marl, grayish-green; some beds contain abundant shells (fig. 18). Red clay zones at $471-478$ and $484 \mathrm{ft}$.

503-516 _..... . Sandy basalt conglomerate; rounded pebbles and cobbles.

516-568_...... Basalt, dark-gray; palagonite and calcite in vesicles.
Shells of large Spondylus, 1,121-1,122 ft. Spiroclypeus margaritatus, 1,121-1,126 ft. Marine smaller foraminifers (bolivinids, buliminids, etc.) and ostracodes, 1,165 ft. Marine smaller foraminifers (miliolids and peneroplids) and ostracodes, $1,186 \mathrm{ft}$. Rare Amphistegina, 1,240 ft. Lignitic material with pollen and spores of land plants, $1,240-1,245$ and 1,250-1,255 ft.

Abundant small shallow-water marine gastropods, including Alcyna, Synaptocochelea Leptothyra, Tricolia, Rissoids vermetids, Bittium, Triphora, Seminella, and Willia mia. Pelecypods include arcids, mytilids, Chama, venerids, and tellens. Brackishwater ostracodes (Cyprideis) 137-208 ft. Two species endodontid land snails, 137$165 \mathrm{ft}$. Abundant brackish-water oysters, $141 \mathrm{ft}$. Large Turbo and Trochus, 141-152 ft.

Aragonitic micromollusks at 222, 233, 238, 243 , and $258 \mathrm{ft}$, from higher levels? Brackish-water ostracodes (Cyprideis), 208-245 ft, very abundant at 242-245 ft.

Brackish-water ostracodes (Cyprideis), 245$260 \mathrm{ft}$, very abundant at $245-259 \mathrm{ft}$. Large cardiids, $246-247 \mathrm{ft}$.

Molds of large tellen, $314 \mathrm{ft}$.

Sand composed mostly of Amphistegina and Camerina.

Valvulammina marshallana, 445-446 ft.

Cerithids and venerids abundant, $463-470 \mathrm{ft}$. Salt-water oysters (Pycnodonta) in darkgreen clay, 483-484 $\mathrm{ft}$. Shell bed (501-502 $\mathrm{ft}$ ) of closely packed bivalves (venerids) in green clay (fig. 18); base of marine section. 


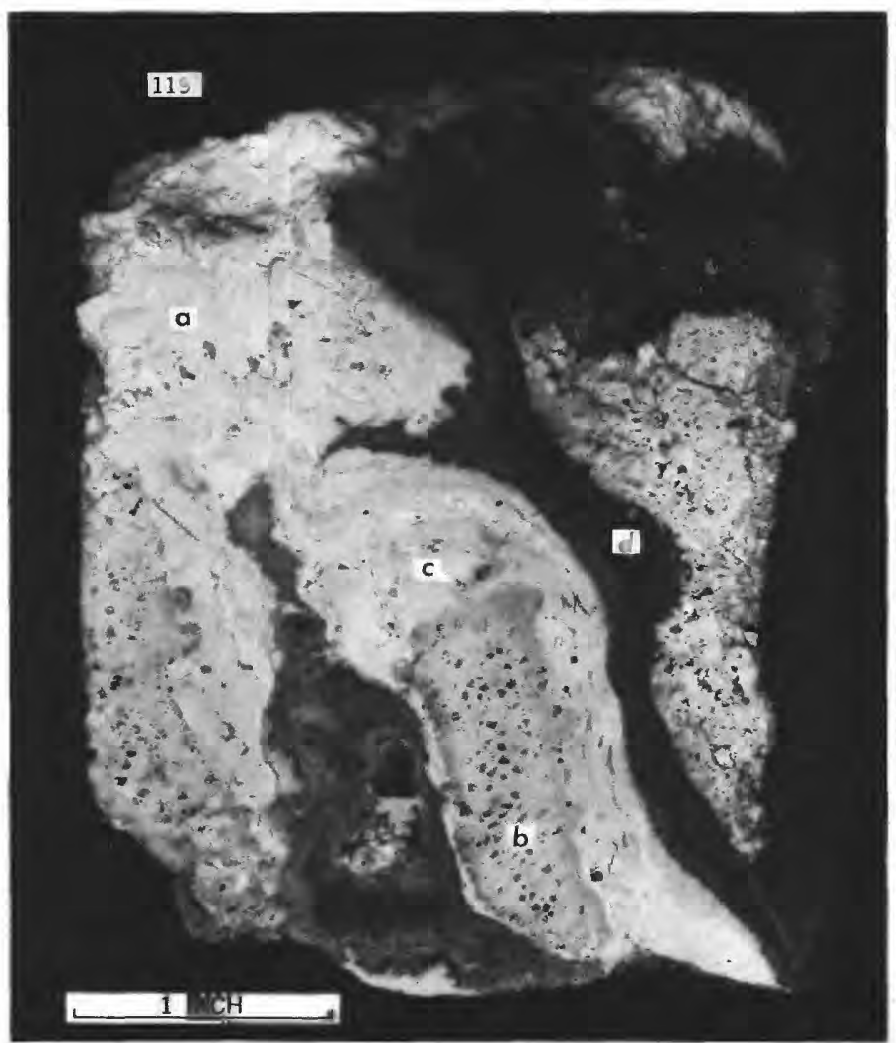

Figure 8.-Reef limestone from the Reef hole at 119 feet. The coralline algae $(a)$ and coral $(b)$ encrusted with algae $(c, d)$ are typical of much of the limestone recovered from the Reef hole at depths less than 208 feet.

The base of the dolomite at 489 feet is apparently an unconformity that marks the top of Tertiary $g$. Carbonaceous clay at 563 feet probably marks the boundary between Tertiary $g$ and $e$. Many voids in the extensively leached limestone from depths of 489 to 633 feet are partly filled with porcelaneous dolomite; dolomite rhombs occur there and at greater depths. Limestone breccia containing dolomite occurs at 588 feet (fig. 11). The section between about 610 and 670 feet has undergone extensive solution and contains large amounts of coarsely crystalline or sparry calcite (Leighton and Pendexter, 1962, p. 60) (fig. 12).

Between depths of about 711 and 934 feet in the Reef hole, the section is composed primarily of lithified fragmental carbonate sediment; intervals of fine to coarse sand are common. Locally, corals or coralline algae are quite abundant, some perhaps in growth positions. The major differences between this part of the section and the overlying section is the absence here of much thick reef or reeflike material apparently still in growth position. Although this part of the section has been thoroughly altered, the limestones are only partly dolo-

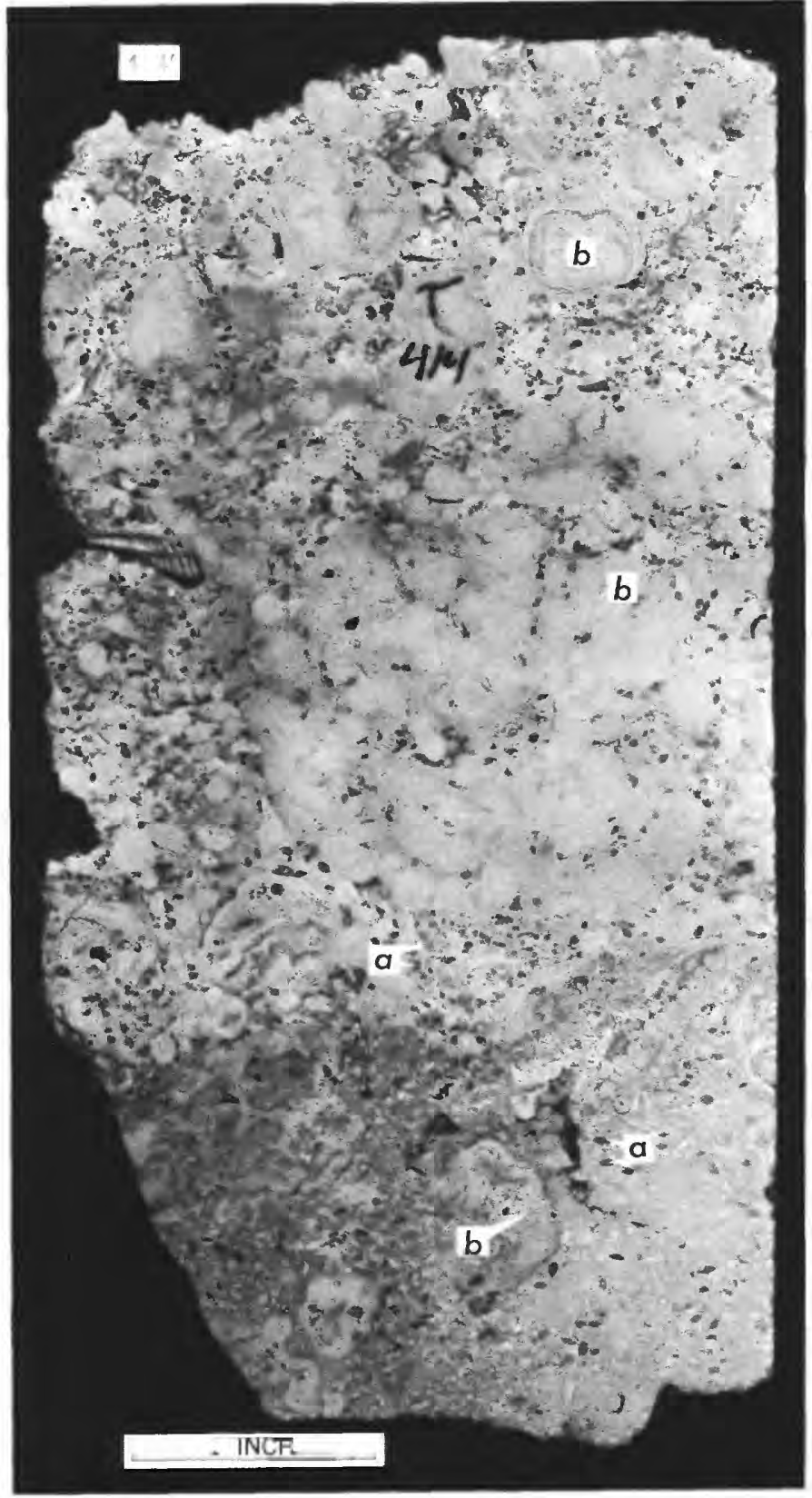

Figure 9. - Fragmental limestone from the Reef hole at 414 feet. Foraminifera $(a)$ and algal fragments and nodules $(b)$ are the most abundant constituents. Note the large algal nodule near the center of the core piece.

mitized (fig. 13); crystalline dolomite is distributed irregularly. Textural features in many of the rocks, especially below 489 feet, indicate complex postdepositional changes that will require petrographic study. It seems that extensive leaching and recrystallization resulting in formation of sparry calcite preceded dolomitization below 489 feet. It is possible, therefore, that all the dolomite below 489 feet formed at the time the section from 426 to 489 feet was extensively dolomitized. 


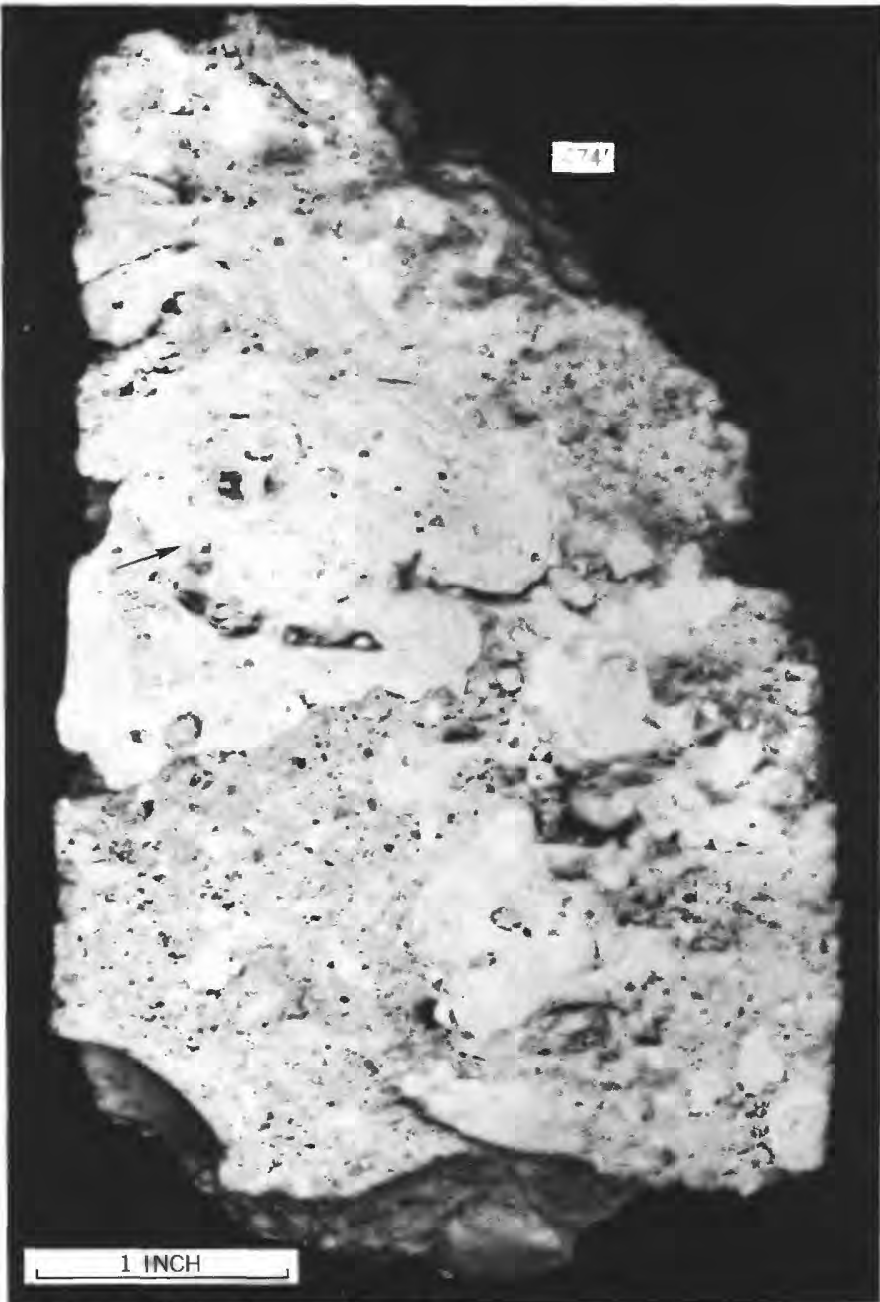

FIGURE 10.-Dolomite from the Reef hole at 474 feet. Note the excellent preservation of the coralline algal structure in the nodule (arrow).

A thin layer of clay is found in the Reef hole at 563 feet. Below 933 feet, volcanic debris is much more abundant. Carbonaceous clay layers occur at 934, 1,050, and 1,116 feet. At 987 feet, mollusk shells occur in a gray clay that contains irregular masses of dark carbonaceous clay (fig. 14). Some typical rocks in this part of the core are partly leached tuffaceous limestone at 993 feet (fig. 15) and 1,030 feet (fig. 16), a molluskbearing carbonaceous layer at 1,046 feet (fig. 17), and a lignitic clay layer that contain abundant land-plant remains at 1,240-1,255 feet.

Below about 1,120 feet, the Reef core contains only seattered carbonate-rich layers; it is primarily weathered volcanic debris. Glauconitelike clay fills foraminifers and ostracodes at the 1,185-foot depth. Again, the carbonate material in this part of the section has been extensively altered but little dolomitized.

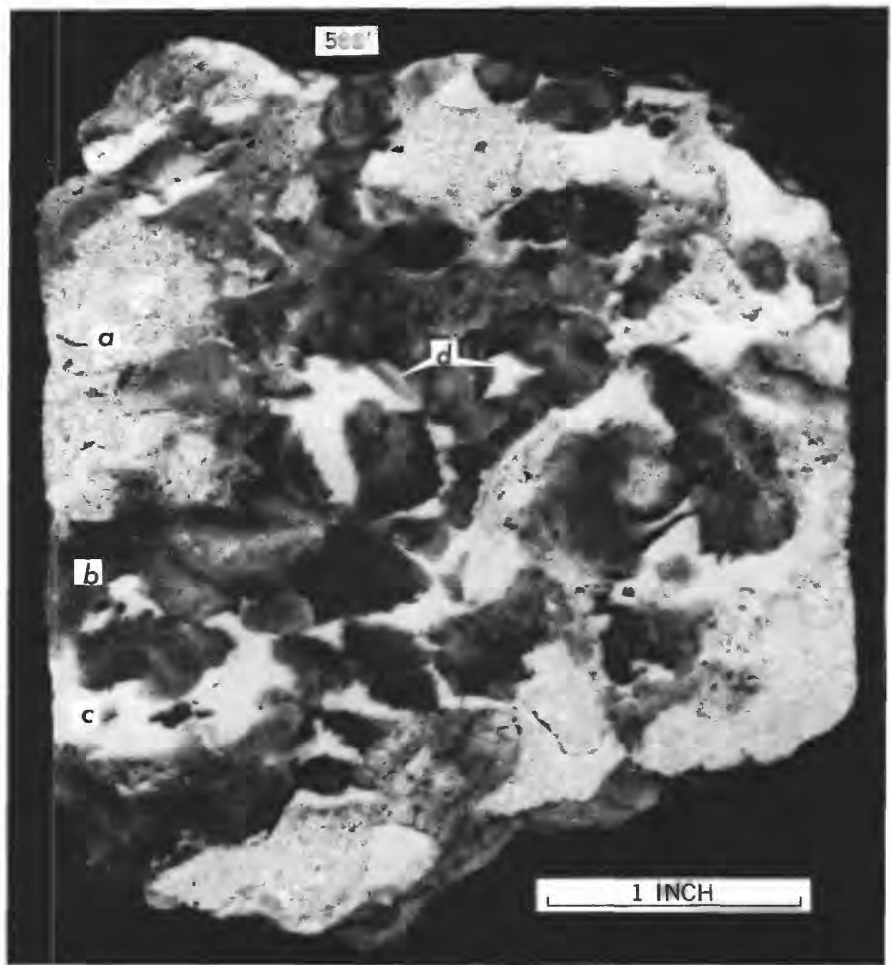

Figure 11.-Dolomitic limestone breccia from the Reef hole at 588 feet. Note that parts of the core $(a)$ retain their original sedimentary structures, whereas other parts $(b)$ are vuglike fillings and masses of sparry calcite. Aphanitic (porcelaneous) dolomite (c) fills most of the interstices. The upper surface (d) of the dolomite filling can be seen in some partly filled voids.

The sedimentary section penetrated in the Sand Island hole differs from that in the Reef hole in that it contains little reeflike limestone and the grain sizes of the original carbonate sediment were much smaller, as one would expect in a lagoonal environment. The section down to about 427 feet is fine-grained fragmental carbonate sediment consisting of abundant foraminifers and mollusks and fragments of corals and algae. Below 208 feet, the sediment is leached and recrystallized and forms hard limestone (fig. 18). Leaching is especially extensive between about 335 and 370 feet. A basalt pebble was recovered at a depth of 405 feet (fig. 18); between about 427 and 443 feet, the conglomeratic limestone contains abundant basalt pebbles. The conglomeratic limestone is at almost the same level as the top of the dolomitized post-Miocene limestone $(426-489 \mathrm{ft})$ in the Reef hole. The conglomeratic limestone overlies foraminiferal limestone, which extends from 443 to 460 feet, and is probably late Miocene in age, and equivalent to the unit between 489 and 563 feet in the Reef hole.

Below about 460 feet, volcanic debris is dominant, although there are layers of oyster shells at $483-484$ feet 


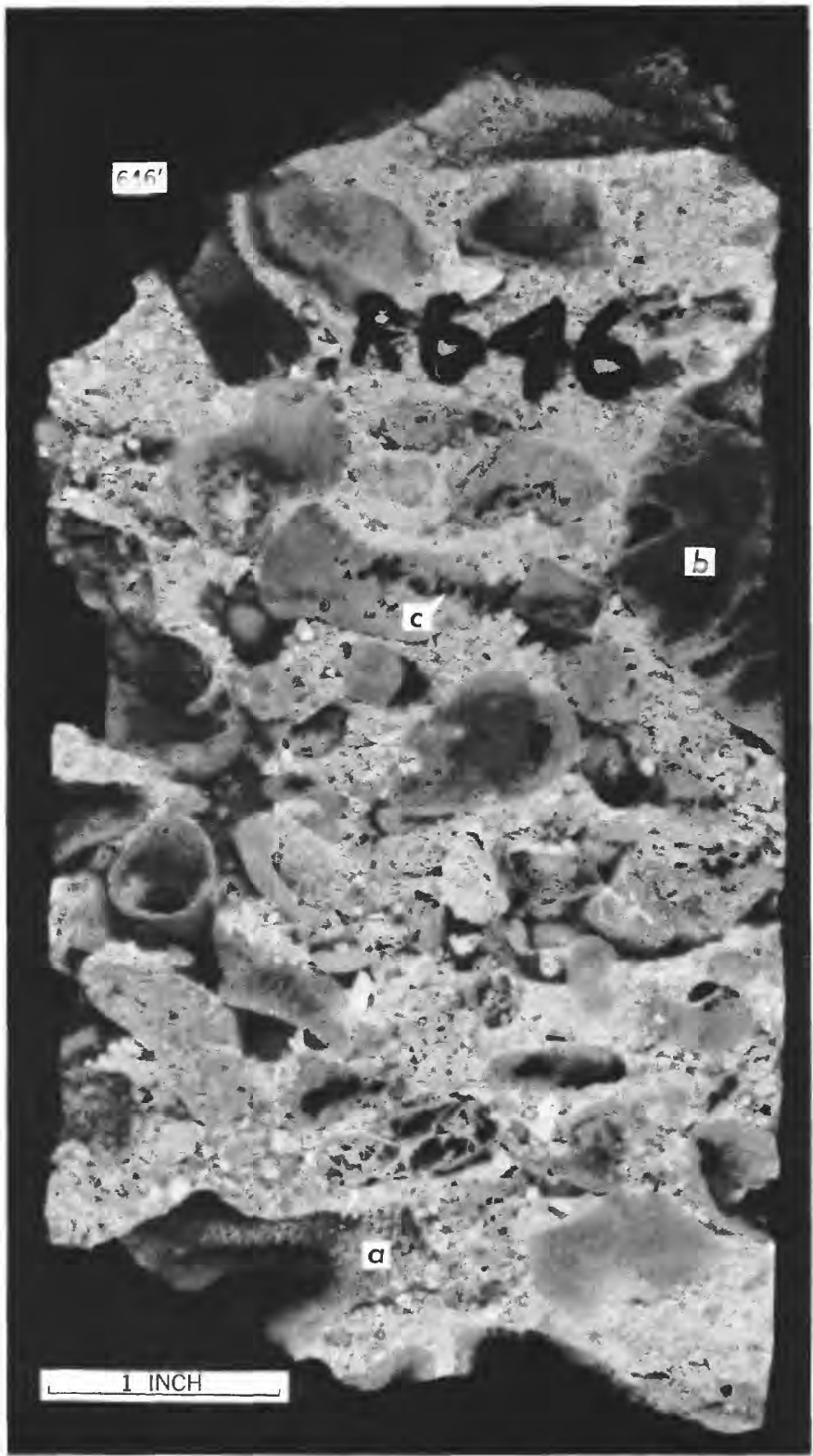

Figure 12.--Extensively leached limestone from the Reef hole at 646 feet. Only empty molds of coral fragments $(a)$ remain. Dark areas $(b)$ are tan sparry calcite. Calcite crystals line many molds and almost completely fill some $(c)$.

and a shell bed at 501-502 feet (fig. 18). Fractured basalt and basalt conglomerate extends from 504 to 516 feet and overlies the basalt.

\section{ORGANIC COMPOSITION AND AGE OF THE SEDIMENTARY SECTION}

Preliminary determinations of the ages of the sediments in the cores are based primarily on the occurrence of diagnostic Foraminifera. W. Storrs Cole of Cornell University is studying the larger forms, and Ruth Todd

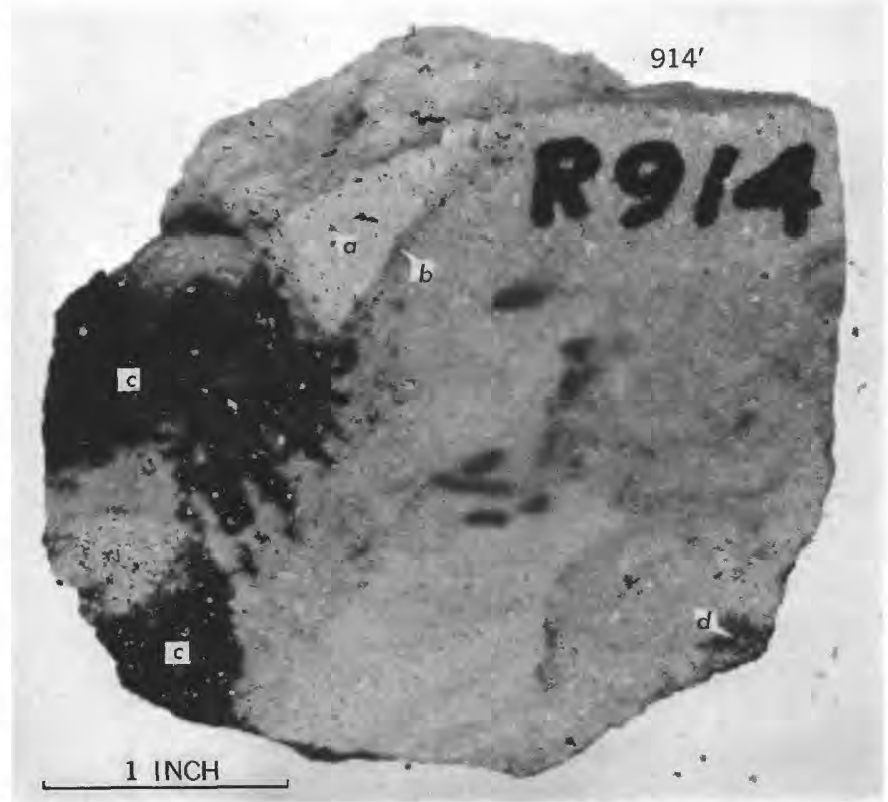

FIgURe 13.-Variegated limy dolomite from the Reef hole at 914 feet. Most of this core piece is limy dolomite and is a mottled pale yellowish orange $(10 Y R 8 / 6)$. A small piece of the core (a) is a limestone which is a very pale orange $(10 Y R 8 / 2)$ and is separated from the rest of the dolomite by 'a rim $(b)$, about 1-2 mm thick, which is grayish orange $(10 Y R 7 / 4)$. Parts of the dolomite are stained $(c)$ dusky red $(5 R 4 / 6)$ and (d) moderate orange pink $(10 R 7 / 4)$. Color designations are based on the "Rock-Color Chart" (Goddard and others, 1948).

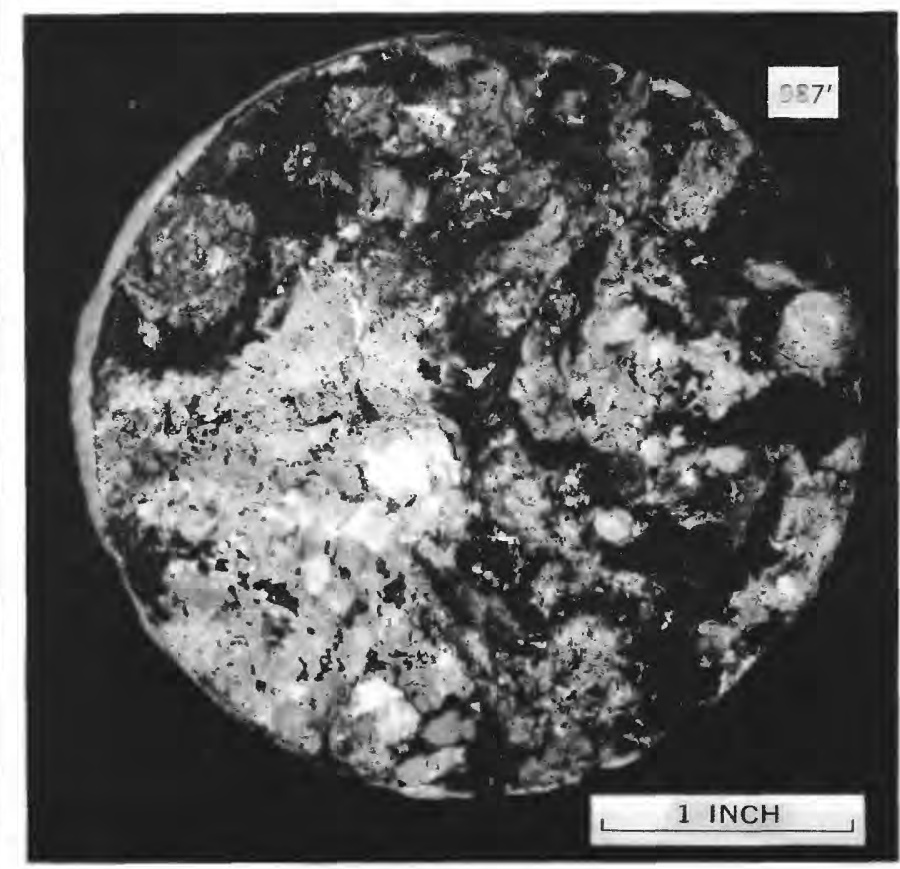

Figure 11.-Fragments of mollusk shells in gray calcareous clay from the Reef hole at 987 feet. Clay contains irregular masses of nearly black carbonaceous clay. 


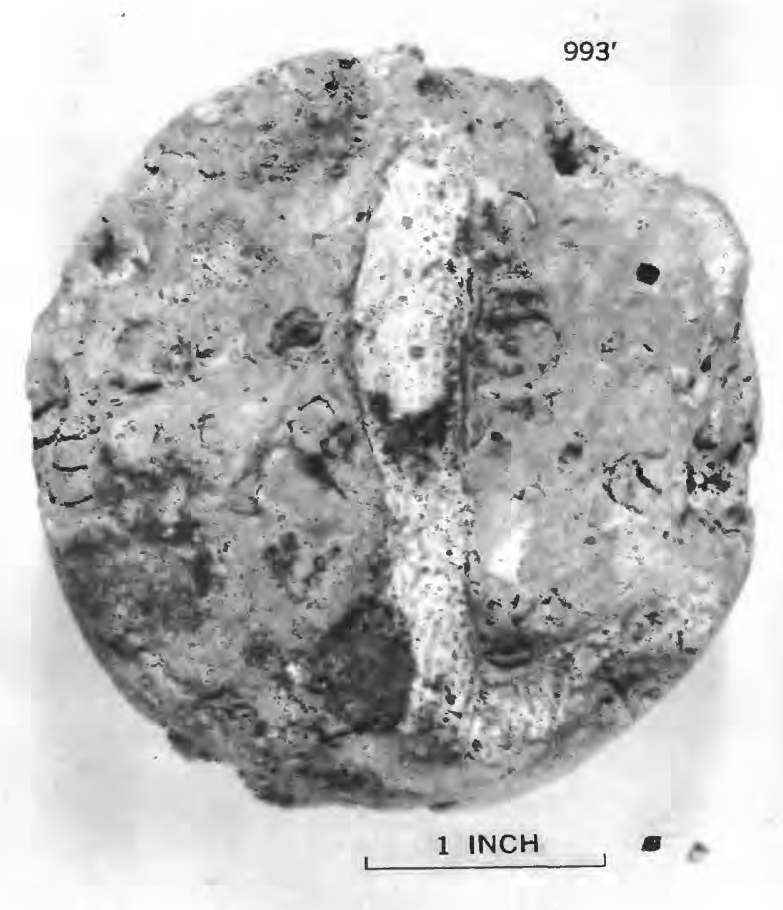

FIgURE 15.-Light-gray tuffaceous limestone containing molds of corals and mollusks from the Reef hole at 993 feet.

and Doris Low of the U.S. Geological Survey are investigating the smaller forms. Their findings are summarized below.

Cole (written commun., 1967) stated:

Five species of larger Foraminifera were recovered. In the lower part of the Reef hole two zones of larger Foraminifera were encountered. The upper zone had abundant specimens of Mriogypsinoides dehaartii (van der Vlerk), 590-927 feet, and Austrotrillina striata Todd and Post, 901-927 feet, and was followed by a zone of spiroclypeus margaritatus (Schlumberger), 960-1126 feet. These three species are known markers for upper Tertiary $e$ (early Miocene) in the western Pacific. This lower section is correlated with sections in the Kita-Daitō-Jima (North Borodino Island) and the Bikini and Eniwetok holes and with surface outcrops of Saipan, Guam, and Borneo.

In the upper part of the drill holes Heterostegina suborbicularis d'Orbigny, Marginopora vertebralis Quoy and Gaimard, and Sorites orbiculus (Forskål) were recovered. These species with a known, relatively long stratigraphic range in the IndoPacific region are not especially diagnostic, except to suggest that the sediments in which they occur are Tertiary $e$ (early Miocene) or younger.

Ruth Todd and Doris Low (written commun., 1967) recognized several assemblages of smaller Foraminifera. They reported:

The reworked clays that underlie the limestones in the Reef hole contain a fauna fairly rich in specimens but poor in species (total 19). The age appears to be early Miocene (Tertiary $e$ ). The assemblage is dominated by bolivinids and buliminids, is

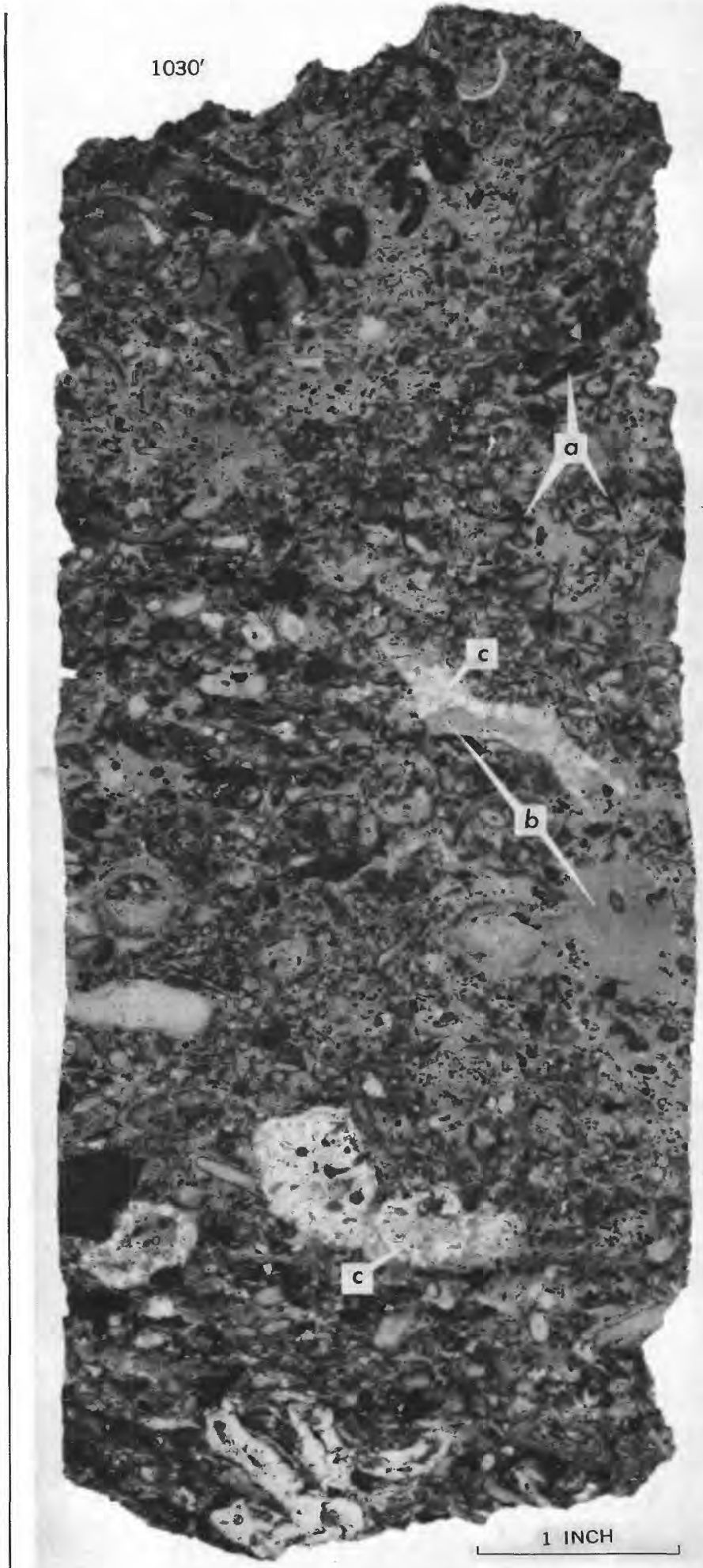

Figure 16. Light-gray $(N 7)$ to medium-light-gray $(N 5)$ tuffaceous limestone from the Reef hole at 1,030 feet. The abundance of molds $(a)$ indicates that leaching has occurred, but some coarsely crystalline calcite fills the molds. An aphanitic limy material fills many interstices and molds $(b)$. Note the large and rather well-preserved coral fragments (c) ; all have a chalky texture. 


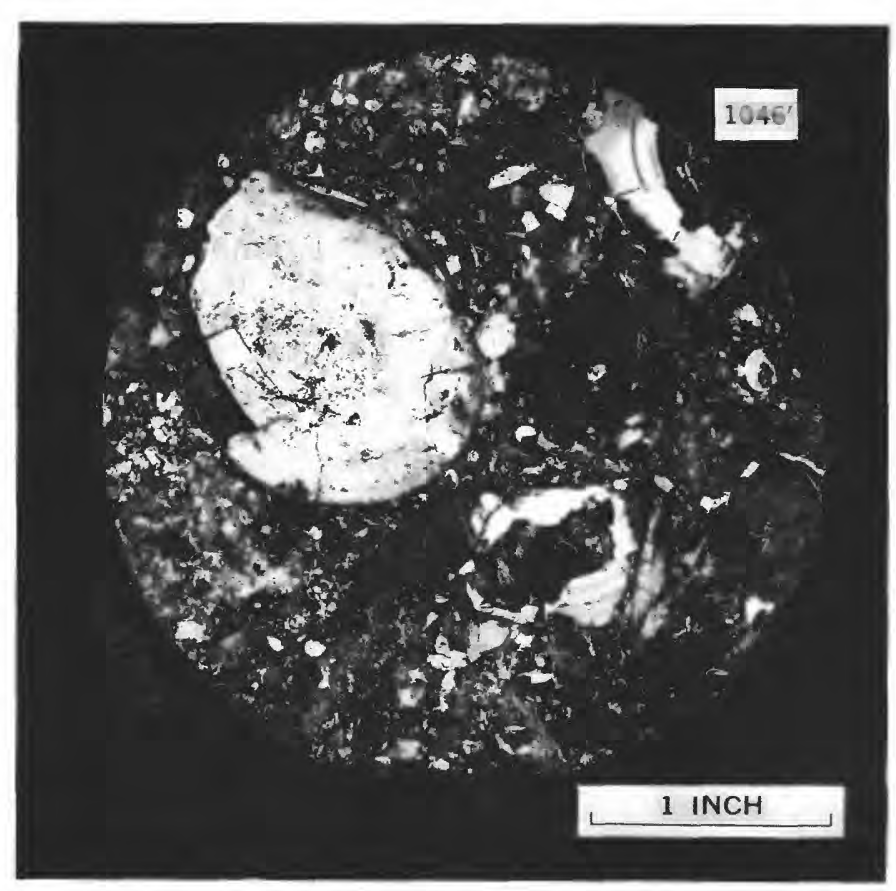

FIGURE 17.-Dark clay from the Reef hole at 1,046 feet containing many shells of bivalves.

definitely marine, and was probably deposited in shallow relatively calm water, near shore or within a lagoon.

In the lower part of the deeper hole, 906-1117 feet, we find Austrotrillina striata Todd and Post. The genus Austrotrillina is believed to have become extinct in the early Miocene (Tertiary e). Its presence at Midway is noteworthy because it is unknown in North or South America and thus far has been reported only from the Tethys basin, from Spain through the Near East and into Australia, and the western Pacific (Saipan, Eniwetok, Bikini).

At a depth of 445 feet in the Sand Island hole and at 495 feet in the Reef hole, the presence of Valvulammina marshallana Todd and Post and other forms suggests a correlation with beds assigned to the late Miocene (Tertiary $g$ ) at Bikini and Eniwetok. (See Todd and Post, 1954, p. 554; Todd and Low, 1960, p. 803 .)

Rich and varied assemblages of smaller Foraminifera occur in the post-Miocene sediments at both sites.

The corals that are an important constituent of the existing reefs were at least equally important in earlier periods of Midway's history. John W. Wells of Cornell University, who is studying both the living reef corals and the fossils from the cores, stated (unpub. data) that the Holocene reef coral fauna of Midway is slightly attenuated, as would be expected with reference to its latitude $\left(28^{\circ} 14^{\prime} \mathrm{N}\right.$.) and its position as an outpost of the Hawaiian fauna. Of the 15 coral genera known to live in the more southerly parts of the Hawaiian chain, nine occur at Midway. Most of these genera are widely ranging in the Indo-Pacific to the outer limits of the tropical zone. The six Holocene genera from Hawaii that have not been found at Midway are exceedingly rare in the Hawaiian Islands. The Miocene coral fauna, according to Wells, was more diversified than later assemblages, suggesting a more favorable regime during the Miocene.

Well-preserved shells of mollusks, many retaining traces of their original color pattern, occur in the carbonate sediments and limestones above a depth of 200 feet in both holes. These shallow-water marine assemblages are typical of reef and lagoon environments but are restricted in numbers and in variety when compared with shallow-water faunas from more tropical areas. The fossil molluscan faunas compare favorably, however, with those now found living on the atoll. The more common molluscan genera are recorded in table 3.

Among the less common marine mollusks is the neritid Pisulina. Four specimens were recovered from the Sand Island hole at depths of 165-180 feet. Living examples of Pisulina are known only from India, Ceylon, and the Amami Islands south of Japan. The only other known fossil occurrence is in upper Miocene (Tertiary $g$ ) beds recovered from a drill hole on Bikini Atoll in the Marshall Islands (Ladd, 1966, p. 59).

Endodontid land snails were found in the upper levels of both Midway drill holes. This group of land snails is not known to live on existing atolls but occurs widely on high volcanic islands or on limestone islands that now rise at least 200 feet above the sea. In the Sand Island hole at depths of 137-165 feet a total of nine minute specimens were recovered. According to Alan Solem (oral commun.), who is monographing the Endodontidae, one of these from a depth of 140 feet belongs to a generalized group which is ancestral to Endodonta. The other eight specimens represent an unusual species that combines the characters of Endodonta and a genus ancestral to it. In the Reef hole, cuttings from depths of 116-130 feet yielded a large specimen of Endodonta s.s., which is related to a species living today on the island of Kauai.

Neither living or dead endodontid shells were found on the existing islands of Midway or Kure, though they are known to be extremely abundant and diversified on the larger volcanic islands of the Hawaiian chain. Such shells (Ptychodon s.l.) have been recovered from drill holes on Eniwetok, Bikini, and Funafuti (fig. 2) and cited as evidence of the temporary emergence of these atolls during Tertiary and later times (Ladd, 1958). The Midway occurrences lend support to similar interpretation. These land snails lived on Midway during the late Pleistocene when it was a "high island." Presumably, the land shells found in the Sand Island hole lived on the higher parts of the island before being washed into the lagoon to be deposited. 

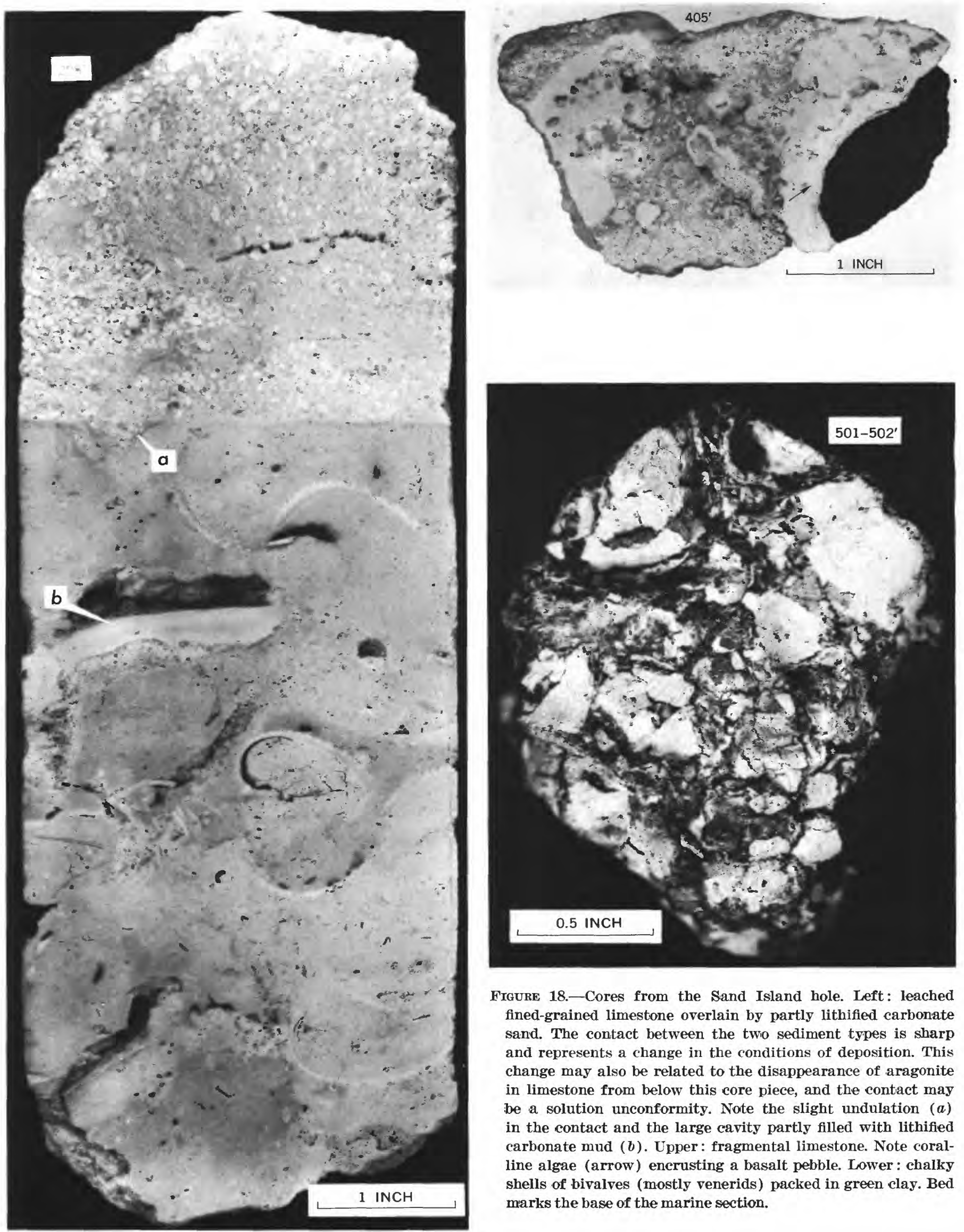

FIGURE 18.-Cores from the Sand Island hole. Left: leached fined-grained limestone overlain by partly lithified carbonate sand. The contact between the two sediment types is sharp and represents a change in the conditions of deposition. This change may also be related to the disappearance of aragonite in limestone from below this core piece, and the contact may be a solution unconformity. Note the slight undulation (a) in the contact and the large cavity partly filled with lithified carbonate mud $(b)$. Upper: fragmental limestone. Note coralline algae (arrow) encrusting a basalt pebble. Lower : chalky shells of bivalves (mostly venerids) packed in green clay. Bed marks the base of the marine section. 
In the leached, recrystallized, and partly dolomitized limestones below depths of 200 feet, large mollusks are fairly abundant at many levels, but most are poorly preserved as molds and calcite casts (fig. 15). Like the younger mollusks, they represent shallowwater assemblages of reef and lagoon. Notably lacking in the Midway cores are the rich assemblages of wellpreserved micromollusks found in the Tertiary $f$ and $g$ sections from drill holes in the Marshall Islands. During Tertiary $f$ time, Midway was probably emergent and undergoing erosion, and all the beds assigned to Tertiary $e$ had been thoroughly recrystallized. Midway was probably also emergent after deposition of the Tertiary $g$ limestone units, which are also thoroughly recrystallized, and before deposition of the dolomite unit above 489 feet in the Reef hole.

The clays below the limestone contain a few layers with abundant fragile shells or impressions of mollusks, mostly bivalves (fig. 18). A bed of salt-water oysters (Pycnodonta) occurs near the base of the Sand Island sedimentary section. In the Reef hole several beds of brackish-water oysters occur between 978 and 995 feet; at 1,046 feet, dark clays contain abundant shells of bivalves (fig. 17).

Joseph E. Hazel, U.S. Geological Survey is studying the fossil Ostracoda. He reported (written commun., 1967 ) that many parts of the cores from both sites have yielded many ostracodes, particularly hemicytherids, bairdiids, and loxoconchids. These are not of immediate value in determining the age of the deposits, as no information is available on the fossil ostracodes of the islands of the open Pacific. Five assemblages are recognized; their generic composition suggests early Miocene to Quaternary ages. All assemblages are normal marine, except those from certain beds in the middle part (137$260 \mathrm{ft}$ ) of the Sand Island hole where the brackishwater ostracode Cyprideis occurs in abundance. The limestones that contain this fauna were probably deposited in a mesohaline lagoon.

Coralline algae are abundant and widespread on the existing reefs of Midway and Kure (frontispiece), and drill cores reveal that they have functioned as important reef builders since early Miocene time. Collections of both Holocene and fossil algae are being studied by Walter H. Adey of the U.S. National Museum.

Lignitic zones were cored in both drill holes and Estella Leopold, U.S. Geological Survey, is examining these. She has found abundant spores and pollen of early Miocene land plants in 12 cores from depths of between 1,240 and 1,255 feet in the Reef hole. Plant tissues were very abundant at three levels; the dominant forms were probably palms and tree ferns. The most diverse assemblage of dicotyledons was found at a depth of $1,251.5$ feet.

Bryozoans are an unimportant constituent of the faunas of existing tropical islands and have left little record in drill cores from other atolls in the open $\mathrm{Pa}$ cific. It was particularly interesting, therefore, to find fossil bryozoans abundant and well preserved in both drill holes on Midway. These bryozoans are being studied by D. A. Brown of Australian National University. Schlanger and Konishi (1966) have shown that bryozoans generally increase in importance as contributors to shallow-water limestones of Tertiary age with increasing distance, both north and south, from the central true tropical zone in the Pacific.

Well-preserved shells of brachiopods were recovered from many levels in both drill holes but never in great abundance or diversity. They are being studied by G. A. Cooper of the U.S. National Museum. The crustaceans and the echinoids left meager records in the sections drilled on Midway, but such fossils as were obtained are being investigated by Henry B. Roberts and Porter M. Kier, both of the U.S. National Museum. The vertebrates, likewise, left a slim fossil record. A collection of minute otoliths is being examined by Donald L. Frizzell of the Missouri School of Mines. Other fish remains include rare teeth. Full reports on all organic groups are being prepared.

\section{BASALTIC FOUNDATION}

The basaltic flows beneath the sedimentary cap of Midway were encountered at a depth of 516 feet in the Sand Island hole and at 1,261 feet in the Reef hole; these depths are much shallower than those predicted by the geophysical surveys (Ladd and others, 1967, p. 1092-1094). As described by Macdonald (1969), the flows are greenish-gray altered basalt with occasional reddish- or yellowish-brown weathered zones. Both aa and pahoehoe types are present; many of the rocks closely resemble subaerial flows in other parts of the Hawaiian chain. The Midway flows were erupted above sea level or in very shallow water. Specimens analyzed from the Reef hole are tholeiitic basalt, but pebbles from sediments overlying the flows include alkalic basalt and mugearite, indicating that the volcano, before becoming quiescent, had entered the late, alkalic stage.

\section{COMPARABLE REEF DRILLING ELSEWHERE}

Midway is the fifth open-sea atoll to be studied by deep drilling (fig. 19) and the second atoll whose limestone cap has been completely penetrated (fig. 20). ${ }^{1}$ Cer-

\footnotetext{
1 After this paper was submitted for publication, we learned that deep drilling on Mururoa Atoll in the Tuamotu group had penetrated more than $400 \mathrm{~m}$ of the limestone cap and $160 \mathrm{~m}$ of the underlying basalt (Chaveau, Jean-Claude, Deneufbourg, Guy, and Sarcia, J. A., 1967, Observations sur l'infrastructure de l'atoll de Mururoa [Archipel des Tou-
} 
TABLE 4.-Data from deep drilling on five atolls in the open Pacific Ocean [Modified from Ladd and others, 1967]

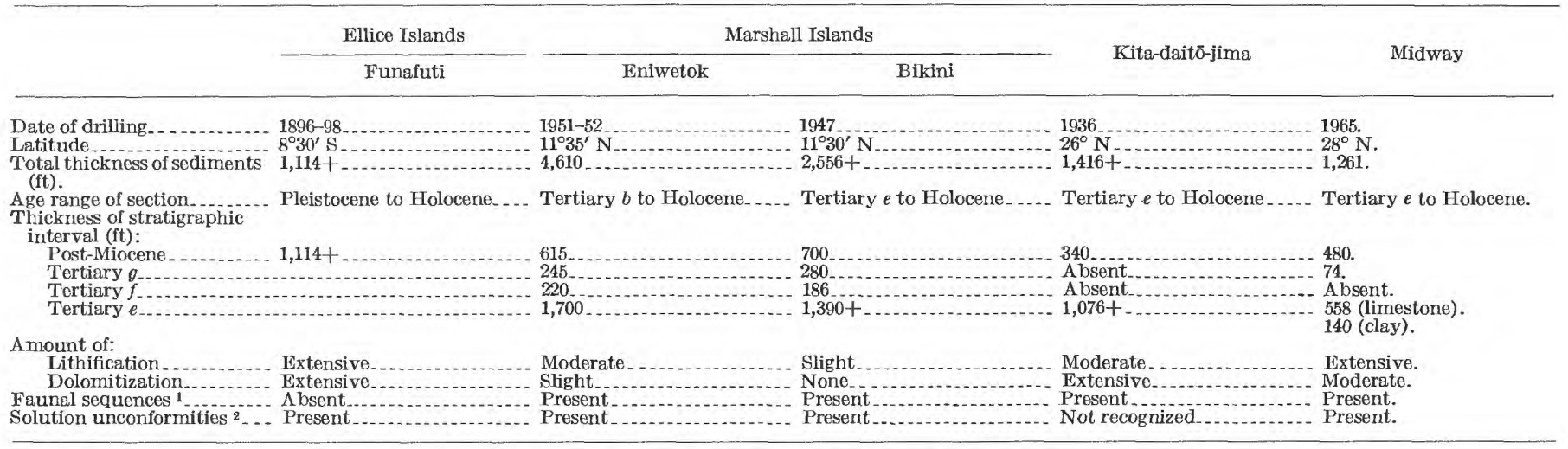

1 These are primarily zones of diagnostic larger Foraminifera that match the 2 Schlanger (1963, p. 994). sequences established in Indonesia.

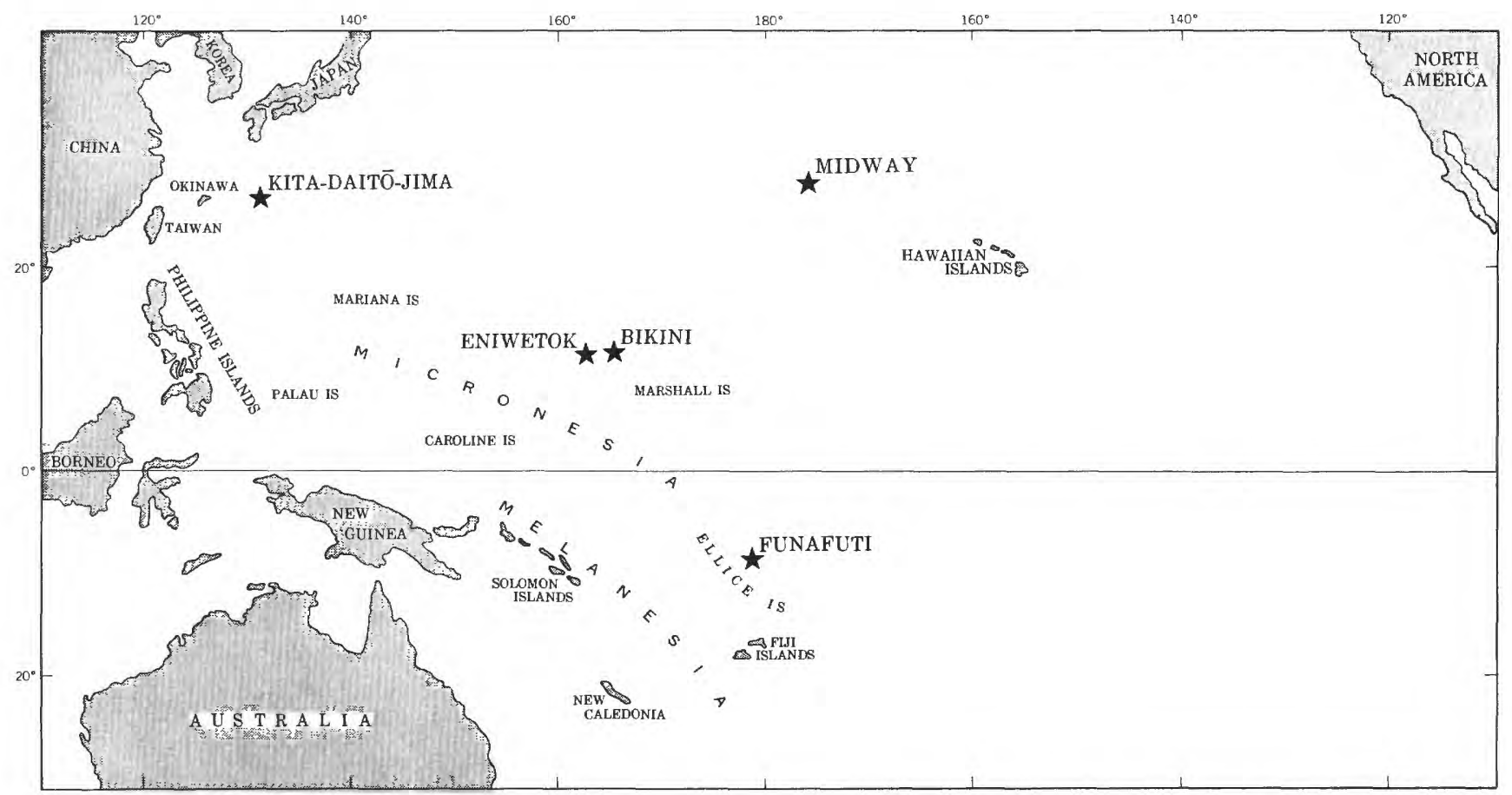

Figure 19. - Sites (stars) of deep holes drilled on five atolls in the open Pacific Ocean. Modified from Ladd and Schlanger (1960).

tain stratigraphic features of the sedimentary sections from the drill cores are listed in table 4 and represented graphically in figure 20 .

amotou, Pacifique Sud]: Acad. Sci. Comptes Rendus, v. 265, Ser. D, p. 1113-1116). The limestone was reported to be fairly massive and re crystallized below about $100 \mathrm{~m}$. $\mathrm{C}^{14}$ and Io/U ${ }^{234}$ dates on samples above $40 \mathrm{~m}$ were obtained (Lalou, Claude, Labeyrie, Jacques, and Delibrias, Georgette, 1966, Datation des calcaires coralliens de l'atoll de Mururoa [archipel des Tuamotu] de l'epoque actuelle jusqu'a $-500,000$ ans : Acad. from sea level to a depth of about $6 \mathrm{~m}, 5,000$ to 8,600 years B.P.; below Sci. Comptes Rendus, v. 263, Ser. D, p. 1946-1949). The following dates were reported: Above sea level, about 3,000 years B.P. (before present) $7 \mathrm{~m}$, generally more than 100,000 years B.P.; and below $19 \mathrm{~m}, 200,000$ to more than 500,000 years B.P. They also reported the presence of dolomite at a depth of $140 \mathrm{~m}$.
The post-Miocene limestones at Midway and at Kitadaitō-jima are thinner than those in the Ellice and Marshall Islands areas. This is of interest in that both Midway and Kita-daitō-jima lie outside the tropies, in what may be called the marginal zones of present reef growth. Funafuti, which lies closest to the equator, has by far the thickest section of post-Miocene rocks. Neither the Midway nor the Kita-daitō-jima sections contain any Tertiary $f$ sediments. Both atolls may have been above the sea and undergoing erosion during this part of the early Miocene.

The limestone sections drilled on Midway (fig. 20) 


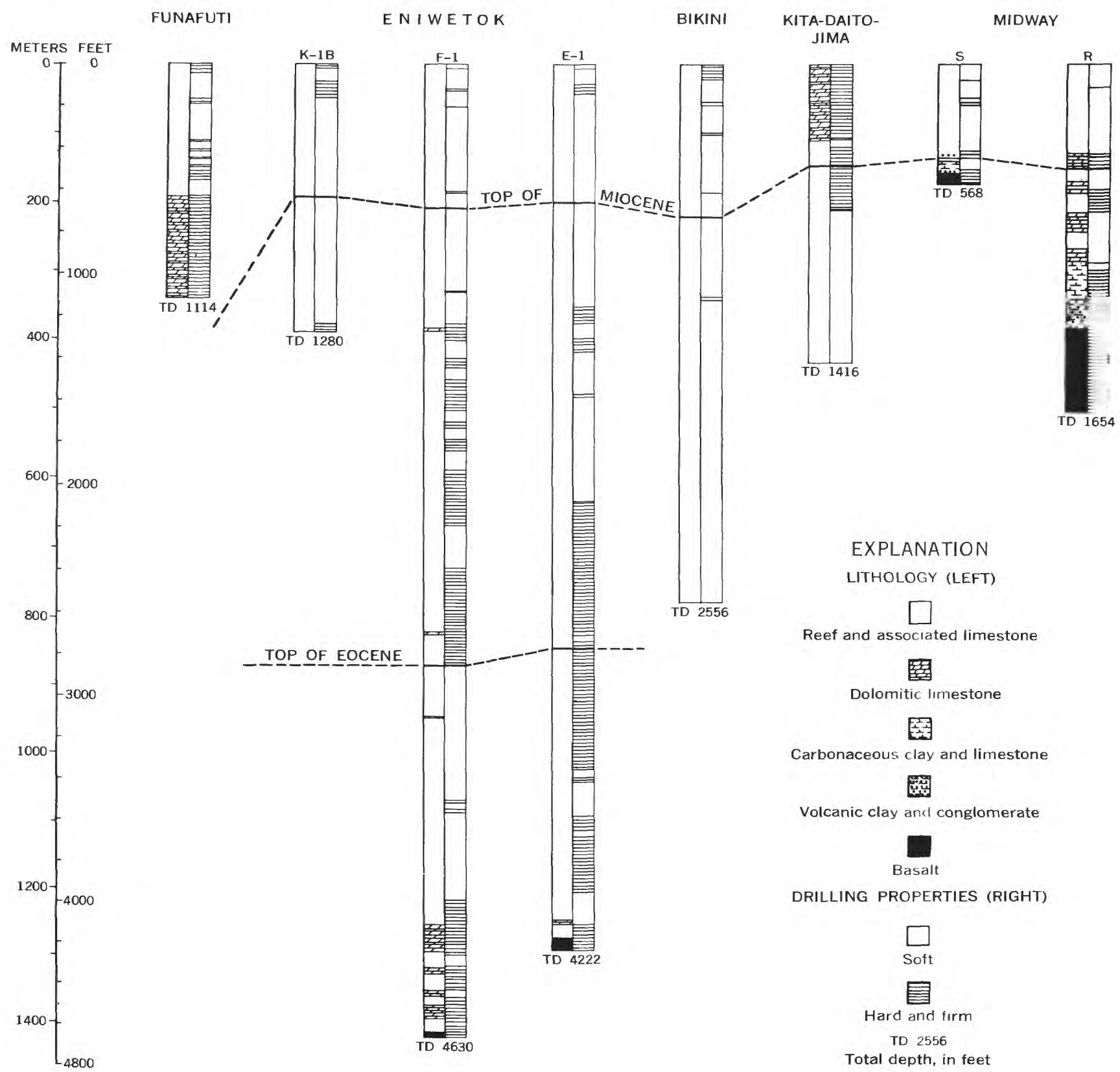

FIGURE 20.- Summary of results of deep drilling on five atolls in the open Pacific Ocean. From Ladd, Tracey, and Gross (1967, fig. 5).

resemible those in the two deepest holes drilled on Eniwetok (E-1 and $\mathbf{F}-1)$ in that all contain appreciable thicknesses of hard and firm recrystallized reef rock but differ in that the Midway sections contain no unaltered aragonitic sediments below the recrystallized limestones. The partly dolomitized carbonate section in the Reef core from Midway is intermediate between the extensively dolomitized sections at Funafuti and Kitadaitō-jima and the slightly dolomitized section at Eniwetok. Dolomite was not detected in the carbonate section at Bikini.
The Midway sections contain beds of volcanic clay and conglomerate above the basalt. In the Reef hole a 187-foot section of bedded carbonaceous and lignitic clay, calcareous volcanic clay, conglomerate, and tuffaceous limestone overlies the basalt. These beds have no counterpart in the other atoll sections.

\section{GEOLOGIC HISTORY OF MIDWAY}

Basaltic lavas poured out at the site of Midway to build a volcanic mound rising nearly 3 miles above the ocean floor. The date at which the mound reached the 
ocean surface is not known, but the flows that capped the old volcano were weathered and were at least partly truncated by wave action by earliest Miocene time.

During earliest Miocene time (Tertiary $e$ ) the northern part of the eroded mound was covered by marine waters, probably less than 100 fathoms in depth. Smaller Foraminifera lived on a bottom covered by volcanic mud. Swamps, now reflected in lignitic layers containing spores and pollen of land plants, alternated with a shallow-marine environment until-following subsidence-a total thickness of 140 feet of sediments, mostly noncalcareous clays, had accumulated.

Subsidence continued; the waters cleared, and reef corals and calcareous algae became established, possibly moving in, from more northerly sites to windward. A total thickness of 560 feet of reef limestone accumulated, probably under lagoonal conditions.

At or near the end of Tertiary $e$ time, the reef emerged, and the entire limestone section and some volcanic hills stood above sea level during Tertiary $f$ time. The limestones were thoroughly leached and recrystallized during this episode. During resubmergence in late Miocene time (Tertiary $g$ ) 75 feet or more of shallowwater lagoonal limestone was deposited. The island was again emergent after deposition of the upper Miocene limestone, which likewise became thoroughly leached and recrystallized.

A further resubmergence apparently continued into Pleistocene time, and about 250 feet of post-Miocene beds accumulated. During or shortly after deposition, the lower 63 feet of this unit was extensively dolomitized, and the irregular dolomitization of the Miocene limestone may have taken place at this time, possibly because of restricted water circulation that permitted local formation of dolomitizing solutions (Newell and others, 1953; Adams and Rhodes, 1960; Deffeyes and others, 1964; Schlanger, 1965). Deposition of the postMiocene limestone was interrupted by another emergence of the atoll, probably due to eustatic lowering of the sea caused by Pleistocene glaciation. Possibly the 200-foot-depth solution unconformity on Midway is related to the 200 -foot submerged bank northeast of Midway and to the extensive submarine platform lying 180 feet below sea level off the island of Molokai and elsewhere in Hawaii. This level, known as the Penguin Bank (Stearns, 1946), is one of four prominent terraces around the Hawaiian Islands. During this period of emergence the newly formed limestones were leached and recrystallized.

After subsidence the altered limestones were covered by about 200 feet of reef and lagoonal sediments. Although these uppermost beds contain two possible solution unconformities, they have not been emergent for long periods and bear little evidence of leaching and no evidence of extensive recrystallization.

The last recorded event was the growth of a now emergent reef, remnants of which are found on most of Midway's rim (fig. $6 D$ ). This reef apparently flourished when sea level was relatively several feet higher than it is now. The oldest of several carbon-14 determinations made on the exposed reef rock by Meyer Rubin of the U.S. Geological Survey gave an age of 2,400 years before present; the youngest, about 1,280 years before present. The old reef is now eroded, and no part now rises more than 3 feet above low-tide level.

A similar but less prominent emergent reef is present on Kure Atoll (Gross and others, 1969) and has been reported from Pearl and Hermes Reef by Galtsoff (1933). These emergent reefs may represent a negative shift in sea level of 5-6 feet, evidence for which has been described from many parts of the Pacific (Wentworth and Palmer, 1925; Stearns, 1941, 1961), or they may represent a very recent emergence of these islands.

\section{REFERENCES CITED}

Adams, J. E., and Rhodes, M. L., 1960, Dolomitization by seepage refluxion: Am. Assoc. Petroleum Geologists Bull., v. 44, p. $1912-1920$.

Austin, B. L., 1959, New rubber-sleeve core barrel gets good cores : Oil and Gas. Jour., v. 57, p. 75-77.

Bryan, E. E., 1906, A report of a visit to Midway Island : Bernice P. Bishop Mus. Occasional Papers, v. 2, no. 4, p. 37-45.

Couthouy, J. P., 1842, Remarks upon coral formations in the Pacific; with suggestions as to the causes of their absence in the same parallels of latitude on the coast of South America : Boston Soc. Nat. History Jour., v. 4, p. 66-105, 137-162.

Dana, J. D., 1843, On the areas of subsidence in the Pacific as indicated by the distribution of coral islands: Am. Jour. Sci., v. 45, p. 131-135.

- 1849, Geology, v. 10 of United States exploring expedition, during the years $1838,1839,1840,1841,1842$, under the command of Charles Wilkes, U.S.N : Philadelphia, 756 p.

Darwin, Charles, 1842, The structure and distribution of coral reefs : London, $214 \mathrm{p}$.

Deffeyes, K. S., Lucia, F. J., and Weyl, P. K., 1964, Observations on the island of Bonaire, Netherlands Antilles: Science, $v$. 143, p. 678-679.

Dietz, R. S., and Menard, H. W., Jr., 1953, Hawaiian Swell, Deep, and Arch, and subsidence of the Hawaiian Islands: Jour. Geology, v. 61, p. 99-113.

Emery, K. O., 1955, Submarine topography south of Hawaii: Pacific Sci., v. 9, p. 286-291.

Galtsoff, P. S., 1933, Pearl and Hermes Reef, Hawaii : Bermice P. Bishop Mus. Bull. 107, 49 p.

Goddard, E. N., chm., and others, 1948, Rock-color chart: Washington, Natl. Research Council [repub. by Geol. Soc. America, 1951], $6 \mathrm{p}$.

Goldsmith, J. R., and Graf, D. I., 1958, Relation between lattice constants and composition of the Ca-Mg carbonates: Am. Mineralogist, v. 43, p. 84-101. 
Goldsmith, J. R., Graf, D. L., and Joensuu, O. I., 1955, The occurrence of magnesian calcites in nature: Geochim. et Cosmochim. Acta, v. 7, p. 212-230.

Gross, M. G., Milliman, J. D., Tracey, J. I., Jr., and Ladd, H. S., 1969, Marine geology of Kure and Midway Atolls, Hawaii-a preliminary report: Pacific Sci., v. 23, p. 17-25.

Hamilton, E. L., 1957, Marine geology of the southern Hawaiian Ridge: Geol. Soc. America Bull., v. 68, p. 1011-1026.

Hess, H. H., 1960, Evolution of ocean basins: Princeton, N. J., Princeton Univ., Dept. Geology Preprint, 38 p.

1965, Mid-oceanic ridges and tectonics of the sea-floor, in Whittard, W. F., and Bradshaw, R., eds., Submarine geology and geophysies, Proceedings of the seventeenth symposium of the Colston Research Society, held in the University of Bristol, April 5th-9th, 1965; London, Butterworth \& Co., p. 317-332.

Ladd, H. S., 1958, Fossil land shells from western Pacific atolls : Jour. Paleontology, v. 32, p. 183-198.

1966, Chitons and gastropods (Haliotidae through Adeorbidae) from the western Pacific islands: U.S. Geol. Survey Prof. Paper 531, 98 p.

Ladd, H. S., and Schlanger, S. O., 1960, Drilling operations on Eniwetok Atoll: U.S. Geol. Survey Prof. Paper 260-Y, p. 863-905.

Ladd, H. S., Tracey, J. I., Jr., and Gross, M. G., 1967, Drilling on Midway Atoll, Hawaii : Science, v. 156, no. 3778, p. 10881094.

Leighton, M. W., and Pendexter, C., 1962, Carbonate rock types, in Ham, W. E., ed., Classification of carbonate rocks-A symposium: Am. Assoc. Petroleum Geologists Mem. 1, p. 33-61.

Macdonald, G. A., 1969, Petrology of the basaltic cores, Midway atoll : U.S. Geol. Survey Prof. Paper 680-B, 10 p.

Malahoff, Alexander, Strange, W. E., and Woollard, G. P., 1966, Molokai fracture zone; continuation west of the Hawaiian Ridge: Science, v. 155, p. 521-522.

Menard, H. W., Jr., 1964, Marine geology of the Pacific: New York, McGraw-Hill Book Co., 271 p.

-1965, The world-wide oceanic rise-ridge system: Royal Soc. London Philos. Trans., ser. A, v. 258, p. 109-122.

- 1967, Extension of northeastern-Pacific fracture zones: Science, v. 155, no. 3758, p. 72-74.

Moberly, Ralph, Jr., and MeCoy, F. W., Jr., 1966, Sea floor north of the eastern Hawaiian Islands: Marine Geology, v. 4, p. $21-48$.

Newell, N. D., Rigby, J. K., Fischer, A. G., Whiteman, A. J., Hickox, J. E., and Bradley, J. S., 1953, The Permian reef complex of the Guadalupe Mountains Region, Texas and New Mexico-a study in paleoecology : San Francisco, W. H.
Freeman and Company, 236 p.

Palmer, H. S., 1927, Geology of Kaula, Nihoa, Necker, and Gardner Islands, and French Frigate Shoal [Hawaiian Islands] : Bernice P. Bishop Mus. Bull. 35, 35 p.

Schlanger, S. O., 1963, Subsurface geology of Eniwetok Atoll : U.S. Geol. Survey Prof. Paper 260-BB, p. 991-1066.

1965, Dolomite evaporite relations on Pacific islands: Tohoku Univ. Sci. Repts., 2d ser. (Geology), v. 37, p. 15-29.

Schlanger, S. O., and Konishi, K., 1966, Contrasting bryozoan content of Plio-Pleistocene to present-day carbonates from Guam, Mariana Islands, and Kikai-jima, Ryukyu Islands, and its regional implications [abs.], in Pacific Sci. Cong., 11th, Tokyo, 1966, Proc.: v. 4, p. 35.

Shor, G. G., Jr., 1960, Crustal structure of the Hawaiian Ridge near Gardner Pinnacles: Seismol. Soc. America Bull., v. 50, no. 4 , p. 563-573.

1963, Coral thickness at Midway Atoll: Scripps Inst. Oceanography Tech. Memo. 136, $3 \mathrm{p}$.

1964, Thickness of coral at Midway Atoll: Nature, v. 201, no. 4925 , p. 1207.

Shor, G. G., Jr.. Phillips, R. P., and Kirk, H. K., 1961, Measurements of coral thickness at Midway lagoon: Scripps Inst. Oceanography Marine Phys. Lab. SIO Ref. 64-14, 12 p.

Stearns, H. T., 1941, Shore benches on north Pacific Islands: Geol. Soc. America Bull., v. 52, p. 773-780.

1946, Geology of the Hawaiian Islands: Hawaii Div. Hydrography Bull. 8, $106 \mathrm{p}$.

1961, Eustatic shorelines on Pacific islands: Zeitschr. Geomorphologie Supplementband 3, p. 3-16.

1966, Geology of the State of Hawaii : Palo Alto, Calif., Pacific Books, 266 p.

Todd, Ruth, and Low, Doris, 1960, Smaller Foraminifera from Eniwetok drill holes: U.S. Geol. Survey Prof. Paper 260-X, p. $799-861$.

Todd, Ruth, and Post, Rita, 1954, Smaller Foraminifera from Bikini drill holes: U.S. Geol. Survey Prof. Paper 260-N, p. 547-568.

U.S. Naval Oceanographic Office, 1963, Midway Islands, total magnetic intensity contour chart, aeromagnetic survey, 1963: U.S. Naval Oceanog. Office Preliminary Spec. Magnetic Survey Chart.

1966, Geomagnetic surveys 1953-1965: U.S. Naval Oceanog. Office Brochure 3.

Wentworth, C. K., and Palmer, H. S., 1925, Eustatic bench of islands of the north Pacific: Geol. Soc. America Bull., v. 36 , p. 521-544.

Woollard, G. P., and others, 1965, Geological, geochemical, and geophysical studies upon the Hawaiian Ridge: Pacific Sci., v. 19, no. 3, p. 271-396. 